OPEN ACCESS

Edited by:

Youji Wang,

Shanghai Ocean University, China

Reviewed by:

Arnaud Laurent,

Dalhousie University, Canada

Arantza Iriarte,

University of the Basque Country

(UPV/EHU), Spain

Hongjie Wang,

Texas A\&M University, Corpus Christi,

United States

*Correspondence:

II-Nam Kim

ilnamkim@inu.ac.kr

Specialty section:

This article was submitted to

Marine Pollution,

a section of the journal

Frontiers in Marine Science

Received: 21 November 2017

Accepted: 14 February 2018

Published: 02 March 2018

Citation:

Lee J, Park K-T, Lim J-H, Yoon J-E and Kim I-N (2018) Hypoxia in Korean Coastal Waters: A Case Study of the

Natural Jinhae Bay and Artificial

Shihwa Bay. Front. Mar. Sci. 5:70.

doi: 10.3389/fmars.2018.00070

\section{Hypoxia in Korean Coastal Waters: A Case Study of the Natural Jinhae Bay and Artificial Shihwa Bay}

\author{
Jiyoung Lee ${ }^{1,2}$, Ki-Tae Park ${ }^{3}$, Jae-Hyun Lim ${ }^{4}$, Joo-Eun Yoon ${ }^{1}$ and II-Nam Kim ${ }^{1 *}$ \\ ${ }^{1}$ Department of Marine Science, Incheon National University, Incheon, South Korea, ${ }^{2}$ Research Institute of Basic Sciences, \\ Incheon National University, Incheon, South Korea, ${ }^{3}$ Division of Polar Climate Sciences, Korea Polar Research Institute, \\ Incheon, South Korea, ${ }^{4}$ Marine Environmental Impact Assessment Center, National Institute of Fisheries Science, Busan, \\ South Korea
}

Several coastal regions in Korea have suffered from hypoxia since the 1970s. We present the first review of Korean coastal hypoxia, focusing on its spatiotemporal variation, controlling factors, and effects on marine ecosystems. The review considers the two hotspots of the natural Jinhae Bay (JB) and artificial Shihwa Bay (SB), which are referred to as "Korean dead zones." The hypoxia in the JB is attributed to eutrophication due to domestic and land-used waste input and thermal stratification based on the naturally sluggish water circulation, whereas the hypoxia in the SB is due to eutrophication resulting from domestic, land-used, and industrial waste input and haline stratification as a consequence of the artificially created water stagnation. The bottom-water hypoxia and stratification has led to an imbalance in nitrogen:phosphorus ratio between surface and bottom waters. Hypoxia has also created undesirable benthic community changes in the both bays: (1) mass mortality of large species and recolonization with elevated abundances of opportunists in JB, and (2) decrease of the number of species, abundance, and diversity of benthic communities in SB. Therefore, it behooves us to pay attention to these environmental changes. This review will be helpful in determining the direction of future studies of Korean coastal hypoxia.

Keywords: coastal hypoxia, eutrophication, Korean coast, Jinhae Bay, Shihwa Bay

\section{INTRODUCTION}

The intensification of anthropogenic activities (e.g., industrialization, urbanization, and agriculture) during the Anthropocene (since the pre-industrial era) has caused a number of serious problems in marine environments, such as acidification and hypoxia, which have become urgent socioeconomic and political issues (IPCC, 2013). Oxygen is a prerequisite for all life on Earth, but "deoxygenation," a term used to express dissolved oxygen (DO) loss, has been dramatically extended and/or enhanced in marine environments (Keeling et al., 2010). The areal extent of coastal hypoxia ( $\mathrm{DO} \leq 2 \mathrm{mg} \mathrm{L}^{-1}$ or $\sim 63 \mu \mathrm{mol} \mathrm{L}^{-1}$ ) has increased remarkably in recent decades due to the increase in coastal eutrophication (Diaz, 2001; Diaz and Rosenberg, 2008; Conley et al., 2009a; Rabalais et al., 2010), leading to significant changes in biogeochemical cycling and marine ecosystem structure (Diaz and Rosenberg, 1995, 2008; Conley et al., 2009b). 
The northern Gulf of Mexico and Chesapeake Bay which receive massive nutrient loadings through river runoff, are frequently referred to as hypoxic coastal regions (Hagy et al., 2004; Dagg et al., 2007; Conley et al., 2009a). In these regions, seasonally chronic hypoxia generally develops through the combination of biogeochemical (i.e., enhanced remineralization) and physical (i.e., strong stratification) effects in the bottom waters, although spatial and temporal variability exists.

In recent decades, to enable the receipt of agricultural and industrial waters, many artificial structures, such as dams and dykes, have been constructed in estuarine systems in East Asia as interfaces between seawater and freshwater (Kim et al., 2001; Tockner and Stanford, 2002; Byun et al., 2004; Cao and Wong, 2007; Acharyya et al., 2012; Lee and Lee, 2012). These artificial structures have unintentionally contributed to the development of coastal hypoxia by restricting water circulation and accumulating organic matter in the water columns and sediments (Portnoy and Giblin, 1997; Byun et al., 2004; Kim T. L. et al., 2006; Lee et al., 2012). A strong cause and effect relationship likely exists between the presence of these artificial structures and the development of coastal hypoxia (Lim et al., 2006; Tsutsumi, 2006). However, few studies have focused directly on this relationship.

Several coastal regions in South Korea have suffered from coastal hypoxia caused by eutrophication, in addition to the effects of the artificial structures (Bashkin et al., 2002; Lim et al., 2006). In the southern coast, bottom-water hypoxia in semi-enclosed Jinhae Bay (JB) and Gamak Bay lasts for several months during the summer. The spatial extent of hypoxia in JB has increased with anthropogenic eutrophication over last four decades threatening benthic ecosystem and aquaculture production (NIFS, 2009). Lim et al. (2006) reported that summer hypoxia cover about $54 \%$ of the total area and has a fatal effect on the benthic ecosystem by creating dead zone in JB (Lim et al., 2006). On the other hand, bottom-water hypoxia in western coast did not occur due to tidal mixing $(3-10 \mathrm{~m})$, which provides wellflushed condition in the coastal area until the dyke construction. Hypoxic bottom waters were first reported in areas adjacent to the river mouth blocked by dykes in the Shihwa Bay (SB), Cheonsu Bay, and Yeongsan Bay (Hong et al., 1997; Lim et al., 2006; Figure 1). Until now, hypoxia has developed in summer months in these bays due to blockage of tidal mixing and water circulation by dyke and results in significant changes in the biogeochemistry and ecosystem structures.

As a result, coastal eutrophication and the presence of artificial structures have caused severe deoxygenation in some Korean coastal regions (Lim et al., 2006). Given that the Korean coastal hypoxia is likely to be unique among hypoxic regions in terms of its causes (i.e., eutrophication and the presence of artificial structures), a review of previous studies of this phenomenon is needed to obtain a comprehensive overview. In addition, coastal hypoxia is regarded as a serious environmental and social problem that urgently needs to be resolved.

The main purposes of this study were: (1) to summarize the key findings of previous studies of Korean coastal hypoxia with a focus on the naturally formed JB and artificially formed SB, which are representatively referred to as "Korean dead zones,"; (2) to provide information regarding its mechanisms, spatiotemporal variation, and biogeochemical and ecological responses; and (3) to identify and address unresolved scientific issues regarding factors controlling the extent of hypoxia and consequences of Korean coastal hypoxia for consideration in future studies.

\section{A BRIEF OVERVIEW OF HYPOXIA IN KOREAN COASTAL WATERS}

Since hypoxia was first reported in JB in September 1974 (Kim et al., 1976), this phenomenon has been considered to be more than just a scientific issue, with catastrophic mass mortality events occurring in the oyster farms of JB due to severe hypoxia in August 1978 (Cho, 1979). Hypoxia has been reported to occur every summer in JB (Cho, 1991; Hong et al., 1991; Lim et al., 2006; Kim Y.-S. et al., 2015; Lee et al., 2017). Since the publication of these reports documenting the hypoxia in JB, coastal hypoxia phenomena have been recorded in other coastal regions (e.g., Cheonsu Bay, Gamak Bay, SB, and Yeongsan Bay; Han and Park, 1999; Kim J. B. et al., 2006, 2015; Lim et al., 2006; Seo et al., 2012; Shin et al., 2013; Jung et al., 2015; Lee et al., 2017). These coastal regions all experience high levels of anthropogenic activity (i.e., rapid industrialization/urbanization and intensive aquaculture systems; Figure 1), resulting in "coastal eutrophication" (Choi et al., 1997; Kim et al., 2005; Kim J. B. et al., 2015; Kim T. L. et al., 2006; Lee and Kim, 2008; Jang J. I. et al., 2011; Lim et al., 2012; Sin et al., 2013). In addition, artificial structures, such as dams and dykes, have been constructed in Cheonsu Bay, SB, and Yeongsan Bay to secure industrial and agricultural waters, leading to very sluggish water circulation (Han and Park, 1999; Lim et al., 2006; Jung et al., 2015).

Eutrophication is regarded as the major cause of the worldwide increase in the number of hypoxic coastal zones since the 1960s (Diaz and Rosenberg, 2008). Hypoxia in Korean coastal waters is caused mainly by eutrophication, due to anthropogenic activities in watersheds over the last 50 years (Lim et al., 2012). These undesirable conditions have resulted in a steep increase in nutrient loading to the coastal waters. Korean coastal regions are currently characterized as severely eutrophic areas and receive the largest terrestrial nitrogen $(\mathrm{N})$ fluxes in the world (Bashkin et al., 2002; Howarth, 2008). Consequently, the frequency of massive algal blooms, such as "red tides," has increased remarkably in Korean coastal regions, and is concentrated mostly along the southern coast, including JB and Gamak Bay (Lee and Min, 1990; Kim, 1997; Lee and Kim, 2008; Lee et al., 2013). These blooms make major contributions to the development of hypoxia in Korean coastal regions (Lee and Kim, 2008), leading to substantially enhanced biological oxygen consumption in water columns and sediments (Diaz, 2001).

The distribution of the minimum DO values recorded during the period of 2009-2016 in Korean coastal regions is shown in Figure 1. Low DO values (red dots, $\mathrm{DO} \leq 2 \mathrm{mg} \mathrm{L}^{-1}$; pink dots, 2 $<\mathrm{DO}<4 \mathrm{mg} \mathrm{L}^{-1}$ ) are distributed mostly in five regions; two along the southern coast (i.e., the red dots in JB and Gamak Bay) and three along the western coast (i.e., the red dot in SB and pink dots in Cheonsu Bay and Yeongsan Bay). Although 


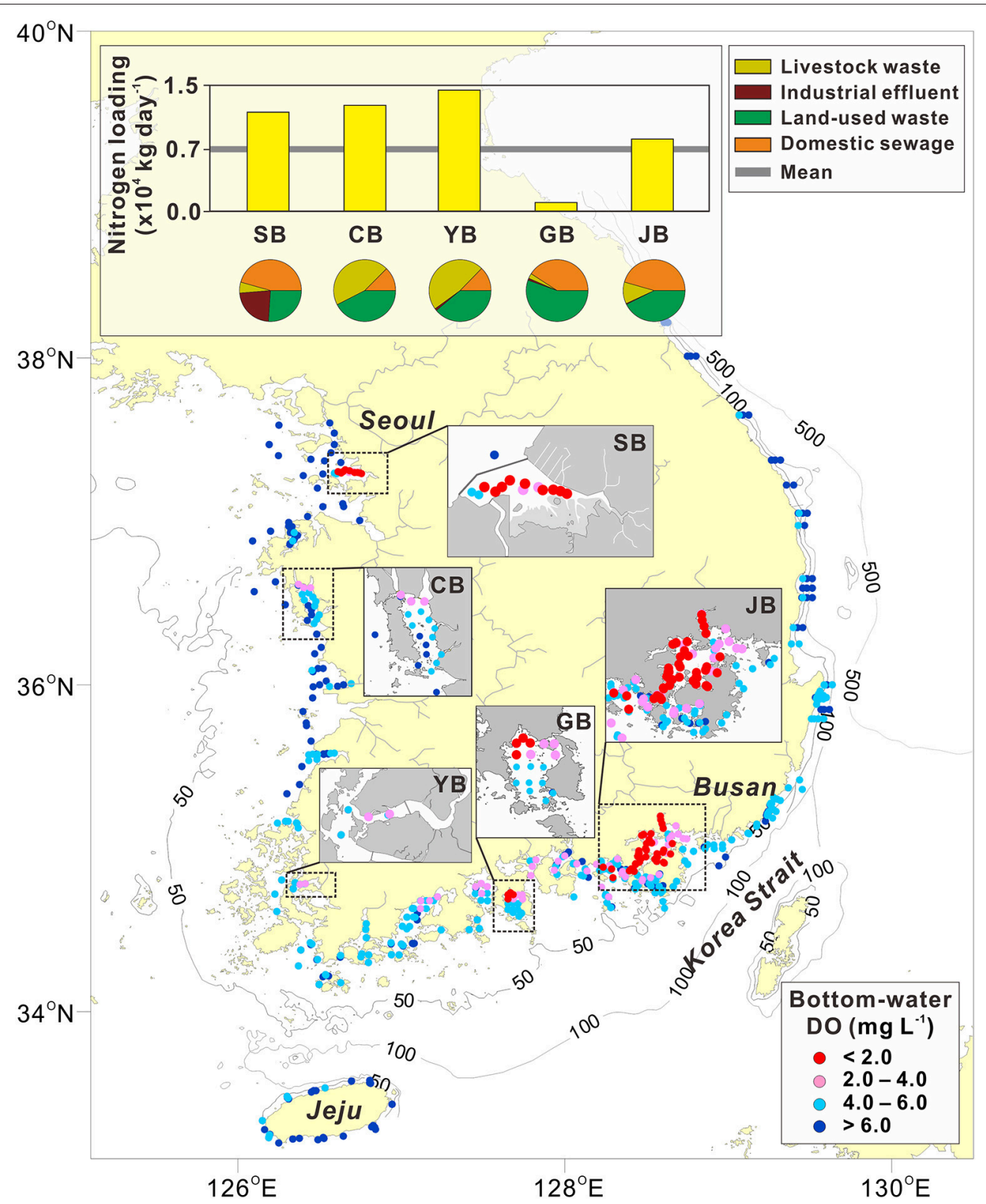

FIGURE 1 | A map showing the minimum values of bottom-water dissolved oxygen (DO) recorded in Koran coastal waters. Five representative hypoxic regions - Shihwa Bay (SB), Cheonsu Bay (CB), Yeongsan Bay (YB), Gamak Bay (GB), and Jinhae Bay (JB) - are highlighted on the map. Most DO data used in the construction of this figure was obtained from the Fishing Ground Environment Monitoring program conducted during 2009-2016 by the National Institute of Fisheries Science (http://www.nifs.go.kr/femo/), but the SB DO data were obtained from the Ministry of Oceans and Fisheries (MOF) reports (MOF, 2005, 2006, 2007, 2008, 2009, 2010, 2011). The inset indicates the total nitrogen ( $N$ ) loading (yellow bars) and contributions (pie charts) of the four major $N$ sources (livestock waste, yellow; industrial effluent, brown; land-used waste, green; domestic sewage, orange) discharged to the watershed in each bay (data source, MOF, 2013). The solid gray line indicates the mean value of the total $\mathrm{N}$ loading in the Korean coastal region. The dots represent the bottom-water DO concentrations (red dots, $<2 \mathrm{mg} \mathrm{L}^{-1}$; pink dots, 2-4 $\mathrm{mg} \mathrm{L}^{-1}$; light-blue dots, 4-6 $\mathrm{mg} \mathrm{L}^{-1}$; blue dots, > $6 \mathrm{mg} \mathrm{L}^{-1}$ ).

hypoxic conditions ( $\mathrm{DO} \leq 2 \mathrm{mg} \mathrm{L}^{-1}$; red dots) were not apparent in Cheonsu Bay (minimum DO, $2.5 \mathrm{mg} \mathrm{L}^{-1}$ ) and Yeongsan Bay (minimum DO, $3.0 \mathrm{mg} \mathrm{L}^{-1}$ ), these two bays have also been referred to as hypoxic regions in previous studies (Lim et al., 2006; Jung et al., 2015). These five hypoxic regions are all located near major population centers, which deliver large amounts of nutrients into the coastal waters. For example, $\mathrm{N}$ loading in these hypoxic regions $\left(0.9-1.4 \times 10^{4} \mathrm{~kg} \mathrm{day}^{-1}\right)$, except in Gamak Bay, is much greater than the mean value for all coastal regions $\left(0.7 \times 10^{4} \mathrm{~kg} \mathrm{day}^{-1}\right.$; shown on the bar graph inset into Figure 1). Thus, excessive nutrient inputs are generally favorable for hypoxia development in coastal regions (Lim et al., 2012). The main $\mathrm{N}$ sources are livestock waste, industrial effluents, land-used waste, and domestic sewage. Livestock and land-used waste are 
the dominant $\mathrm{N}$ sources in Cheonsu Bay and Yeongsan Bay, whereas domestic sewage, land-used waste, and industrial waters are the dominant $\mathrm{N}$ sources in Gamak Bay, JB, and SB (MOF, 2013).

In addition to coastal eutrophication (a biogeochemical factor), seasonal stratification (a physical factor) blocks the vertical exchange between surface and bottom waters, and is an important factor in the establishment of hypoxia (Rabalais et al., 2001). Strong stratification has developed in five of the hypoxic regions due to thermal and/or haline effects. This physical isolation has resulted in weak or absent vertical and horizontal water circulation (Han and Park, 1999; Jung et al., 2015; Lee et al., 2017). The extremely sluggish water circulation in JB and Gamak Bay is a natural phenomenon associated with the regional geomorphology and hydrology, whereas it is driven by artificial structures in Cheonsu Bay, SB, and Yeongsan Bay (Figure 1). Therefore, Korean coastal hypoxic regions can be categorized systematically as a natural or artificial bay system.

In the following section, we describe Korean coastal hypoxia in terms of its spatial and temporal variation, main controlling factors, and effects on marine ecosystems through an analysis of the two significant systems. We first consider JB, as a representative natural system, and then consider $\mathrm{SB}$, as an artificial system.

\section{HYPOXIA IN THE NATURAL SYSTEM OF JB}

\section{General Characteristics}

JB is located on the southeastern Korean coast (Figure 1), and is a shallow (mean depth, $\sim 20 \mathrm{~m}$ ) semi-enclosed bay with many islands. Geomorphologically, it consists of seven sub-bay systems: Masan Bay, Jindong Bay, Danghang Bay, Dangdong Bay, Wonmun Bay, Gohyeon Bay, and Haengam Bay (Figure 2). Gadeok Channel is the primary pathway for the exchange of seawater between JB and the South Sea (Figure 2). Geographic complexity and isolation have led to the natural development of extremely sluggish water circulation (mean rates of bottom-water flow: 8 (neap tide) -10 (spring tide) $\mathrm{cm} \mathrm{s}^{-1}$ ) in JB (Hong, 2016; Kim et al., 2016). During the summer, low-salinity water, formed mainly by freshwater discharge from a number of small streams and heavy precipitation from the Asian monsoon, occupies the surface layer of JB, partially contributing to the development of stratification (Cho et al., 2002; Kim S.-Y. et al., 2012).

JB was the most important spawning and nursing ground for fish and shellfish in the Korean coastal water until the 1970s (Cho, 1991). Since then, anthropogenic activities, such as rapid industrialization/urbanization and intensive aquaculture development, have resulted in massive nutrient loading. As shown in Figure 1, the discharge of domestic sewage (orange) and land-used waste (green) is estimated to be 3,800 and $3,600 \mathrm{~kg}$ day $^{-1}$, respectively, representing the dominant $\mathrm{N}$ sources. The massive nutrient loading has resulted in the deterioration of water quality in JB; it has become the most eutrophic bay along the Korean coast (Kim D. et al., 2012; Kwon et al., 2014). As a result, JB has suffered from chronic anthropogenically derived environmental problems, such as seasonal hypoxia, water quality deterioration, and harmful algal blooms (Lim et al., 2006; Lee and Kim, 2008; Kim et al., 2014). To resolve or relieve these problems, various conservation and management policies have been introduced by national and regional governments over the last few decades. These policies have included dredging, wastewater treatment, and regulation of total pollutant loading, but these actions have proven to be ineffective (Chang et al., 2012). Therefore, JB has experienced serious environmental problems for a long time; in particular, it has suffered from severe coastal hypoxia since the 1970s (NIFS, 2009).

\section{Temporal and Spatial Distribution of Hypoxia}

In JB, severe hypoxia usually occurs in the bottom waters from May to September, although some interannual variation exists (Kim et al., 2002; Lim et al., 2006; Kim J. B. et al., 2015; Lee et al., 2017). Figure 3 shows that bottom-water DO concentrations are $10 \mathrm{mg} \mathrm{L}^{-1}$ in winter (January-February) due to active vertical mixing. Bottom-water DO concentrations then decrease sharply from 10 to $2 \mathrm{mg} \mathrm{L}^{-1}$ in spring (March-May) due to the great accumulation of organic matter from eutrophication, leading to hypoxia. In addition, the temperature difference between the surface and bottom waters begins to increase (i.e., $\Delta \mathrm{T}=\mathrm{T}_{\text {surface }}{ }^{-}$ $\mathrm{T}_{\text {bottom }}>0^{\circ} \mathrm{C}$ ), stabilizing the water-column structure. Hypoxic bottom waters persist during summer (June-August; DO $<2 \mathrm{mg}$ $\mathrm{L}^{-1}$ ), along with strong thermal stratification (mean $\Delta \mathrm{T}=6^{\circ} \mathrm{C}$ ). Bottom-water DO concentrations increase from 2 to $6 \mathrm{mg} \mathrm{L}^{-1}$ in fall (September-October/November) due to thermal cooling and/or wind forcing (NIFS, 2009; Kim Y.-S. et al., 2015; Ye, 2015; Lee et al., 2017), leading to weak stratification and in turn providing ventilation between surface and bottom waters (i.e., $\Delta \mathrm{T}$ toward $0^{\circ} \mathrm{C}$ ). The seasonal variation in bottom-water $\mathrm{DO}$ can be categorized into three phases: the decrease in bottom-water DO leading to the development of hypoxia in spring is phase I, the development and maintenance of bottom-water hypoxia in summer is phase II, and the decrease in bottom-water hypoxia in fall is phase III (Figure 3).

The areas of the world's oceans affected by deoxygenation have been expanding significantly (Keeling et al., 2010), leading to various effects on marine biogeochemical cycling and ecosystems (Diaz and Rosenberg, 2008; Rabalais et al., 2010). In the global context, the areal extent of the JB summer hypoxia has increased remarkably (Figure 4), with reported values of $197 \mathrm{~km}^{2}$ in 1989 (Lim et al., 2006), $209 \mathrm{~km}^{2}$ in 1993 (Kim and Lee, 1994), and 272 $\mathrm{km}^{2}$ in 2010 (Kim S.-Y. et al., 2012). Until the 1980s, bottomwater hypoxia was observed only in the southwestern regions of JB (i.e., Dangdong Bay, Wonmun Bay, and Gohyeon Bay) and in the inner Masan Bay (Hong, 1987; Lim and Hong, 1994; Lim et al., 2006; NIFS, 2009).

The hypoxia in JB during summer has been studied intensively to characterize its interannual spatial variability (NIFS, 2009; Ye, 2015). A spatial distribution map showing the counted numbers of JB summer hypoxia occurrence (HO) from the total of 16 surveys for the period of August 1990-2016 is given in Figure 2. High numbers of $\mathrm{HO}(\geq 13$, shown in red in Figure 2) were observed in the western regions (Jindong Bay, Dangdong Bay, Gohyeon Bay, and around Gajo Island) and the northeastern 


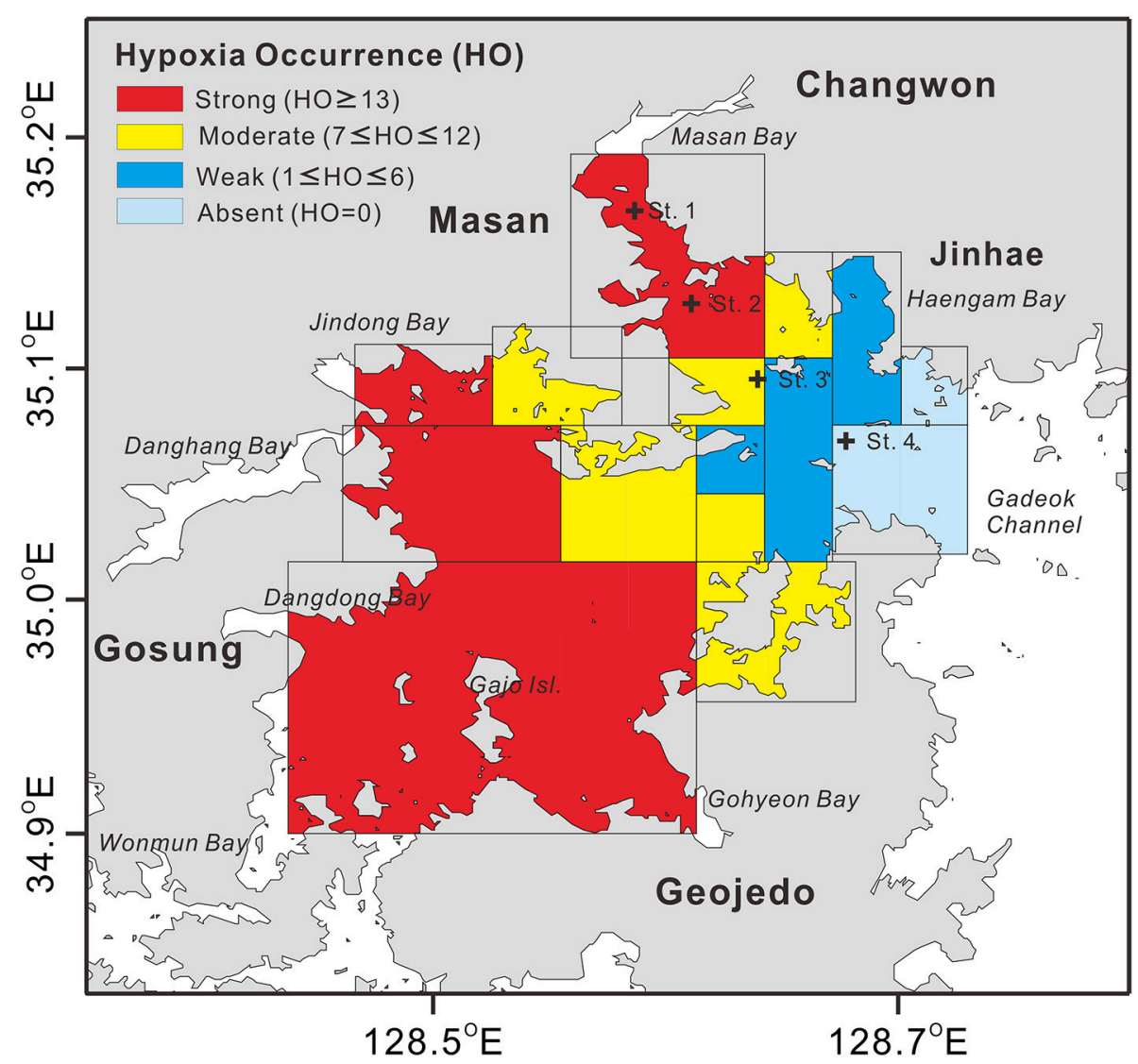

FIGURE 2 | Spatial distribution of the counted numbers of hypoxia occurrence (HO) from a total of 16 surveys conducted during the month of August $1990-2016$ in the Jinhae Bay. The data sources are Kim and Lee (1994), Kim S.-Y. et al. (2012), and annual National Institute of Fisheries Science (NIFS) reports (http://www.nifs.go. $\mathrm{kr} / \mathrm{bbs}$ ?id=seastate). Plus signs $(+)$ represent the locations of benthic community sample collection (see Figure 5). Note that here HO was determined with the criterion of dissolved oxygen $<3 \mathrm{mg} \mathrm{L}^{-1}$ in Figure 2 as the compiled maps showing hypoxia distributions in the Jinhae Bay from the previous studies were mostly based on the criterion of dissolved oxygen $<3 \mathrm{mg} \mathrm{L}^{-1}$.

region (Masan Bay), which have greater nutrient loading and more shellfish farms than do other regions (Lim and Hong, 1994; Lim et al., 2006; Lee et al., 2008; Bae et al., 2010; Ye, 2015). Moderate numbers of $\mathrm{HO}(7 \leq \mathrm{HO} \leq 12$, shown in yellow in Figure 2) were observed in the center of JB, and low numbers of $\mathrm{HO}(1 \leq \mathrm{HO} \leq 6$, shown in blue in Figure 2$)$ were observed near the Haengam Bay. The area near the Gadeok Channel showed no hypoxia $(\mathrm{HO}=0$, shown in light blue in Figure 2), resulting from the active water exchange.

\section{Factors Controlling the Three Phases of Hypoxia: Development, Persistence, and Termination}

JB system has low physical energy due to enclosed geomorphology and limited water circulation, leading to strong seasonal stratification. During phase I, which is the period from March to May when hypoxic conditions form and the bottom-water DO level decreases rapidly toward hypoxia, thermal stratification is developed gradually due to solar heating. As shown in Figure 3, this relationship is supported by the strong negative correlation between the bottom-water DO concentration and $\Delta \mathrm{T}$ in JB (Kim et al., 2010; Kim Y.-S. et al., 2015; Ye, 2015; Lee et al., 2017).

Bottom-water hypoxia persists across a wide region of JB during phase II (i.e., constant DO concentrations of $<2 \mathrm{mg} \mathrm{L}^{-1}$ during summer), resulting from a balance between source and sink processes that influence bottomwater DO concentrations (Figures 2, 3). During summer, the water-column stability is intensified greatly by thermal (i.e., solar heating) stratification, while haline (i.e., freshwater discharge) stratification intermittently strengthens the watercolumn stability (Figure 3) (NIFS, 2009; Kim S.-Y. et al., 2012; Ye, 2015), isolating the bottom-water much more than in the other seasons. A similar feature has also been reported in the western area of Long Island Sound, USA (Welsh and Eller, 1991) and in Seto Inland Sea, Japan (Kasai et al., 2007), where the influence of freshwater is small. Generally, spring freshwater discharge, which leads to haline stratification and enriches the organic matter content due to enhanced primary production, is considered to be the primary factor for the development of hypoxia in other hypoxic coastal regions (e.g., the northern 


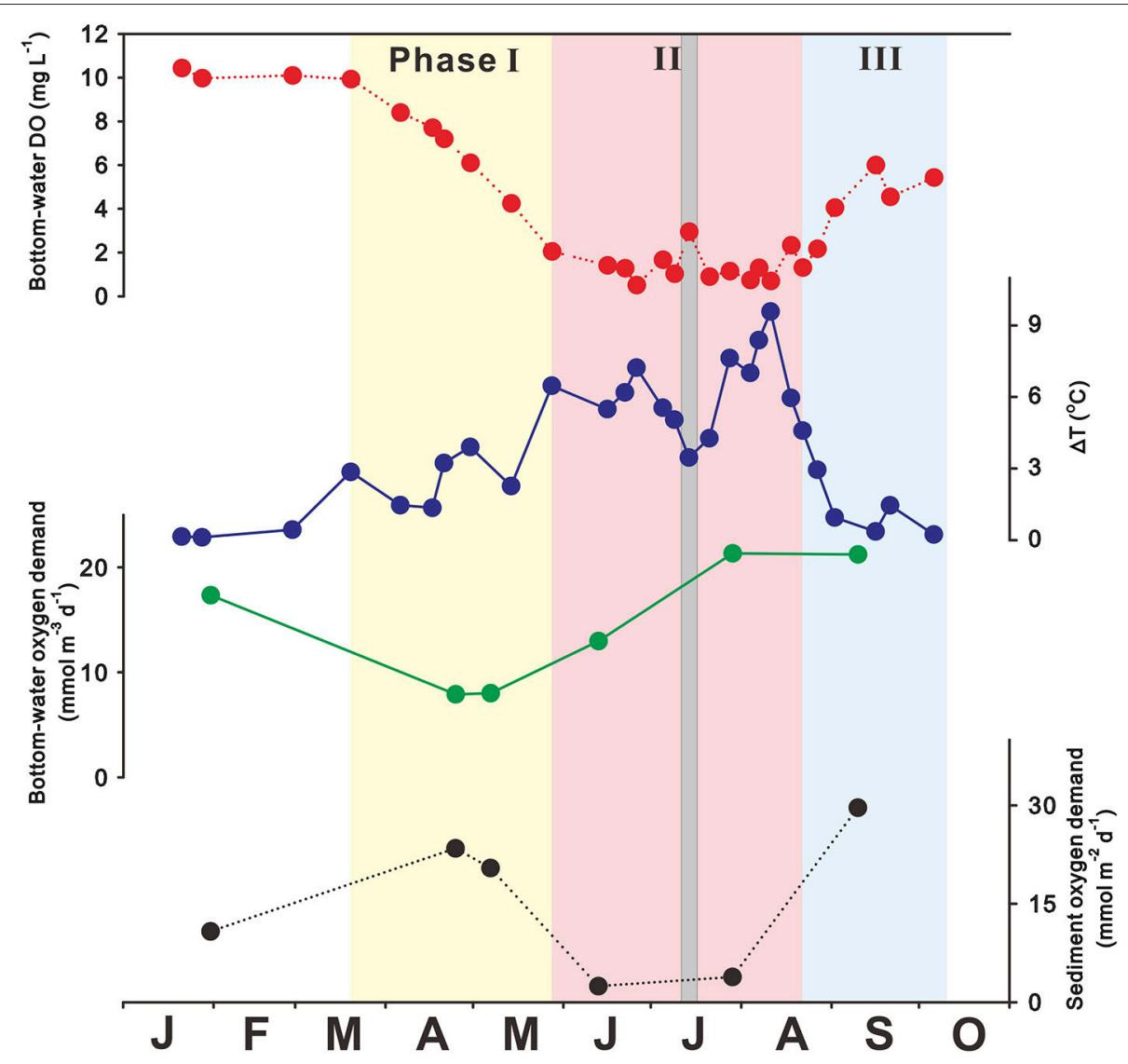

FIGURE 3 | Seasonal variation in bottom-water dissolved oxygen (DO; $\mathrm{mg} \mathrm{L}^{-1}$ ), $\Delta \mathrm{T}$ (i.e., difference between surface and bottom temperatures; $\left.{ }^{\circ} \mathrm{C}\right)$, bottom-water oxygen demand ( $\left.\mathrm{mmol} \mathrm{m} \mathrm{m}^{-3} \mathrm{~d}^{-1}\right)$, and sediment oxygen demand ( $\mathrm{mmol} \mathrm{m} \mathrm{m}^{-2} \mathrm{~d}^{-1}$ ) observed in 2015 in Jinhae Bay. Phases I, II, and III encompass hypoxia development, persistence, and termination, respectively. The gray shading represents the Chan-Hom typhoon, which passed in July 2015 . Source: Adapted from Lee et al. (2017). Reproduced with permission of the Coastal Education and Research Foundation, Inc.

Gulf of Mexico, Chesapeake Bay, and the Baltic Sea; Diaz, 2001; Rabalais et al., 2001; Hagy et al., 2004; Conley et al., 2009a). However, because a large amount of freshwater discharge usually occurs in the summer due to the heavy precipitation that develops from the Asian monsoon, the effect of freshwater discharge on the development of hypoxic conditions in JB during phase I is less important. This relationship is supported by the weak correlation between bottom-water DO concentrations and difference between surface and bottom salinity (i.e., $\Delta S$ ) in JB (Lee et al., 2017).

When JB is under the influence of typhoons during phase II, bottom waters are reoxygenated temporarily. For example, the Chan-Hom typhoon passed over JB on July 14, 2015, with wind speeds of $12.4 \mathrm{~m} \mathrm{~s}^{-1}$ (see solid gray line in Figure 3), resulting in "de-stratification." However, strong water-column stratification occurred again within $\sim 1$ week after the typhoon event and, in turn, bottom-water hypoxia reappeared in the JB as usual (Lee et al., 2017).

The termination of JB bottom-water hypoxia occurs during phase III (i.e., recovery of oxygen-depleted conditions in the bottom-water to form oxygen-replete conditions), and generally results from the destruction of stratification due to thermal cooling and/or elevated wind forcing (NIFS, 2009; Ye, 2015; Lee et al., 2017). The rapid and sharply decreasing $\Delta \mathrm{T}$ from late August to early September is a consequence of weak watercolumn stratification (Figure 3), leading to active vertical mixing between surface and bottom waters.

The physical factors determines where hypoxia can occur, while the biogeochemical factors lead to depletion of oxygen due to elevated supply of organic matter (Rabalais et al., 1999). The delivery of excess organic matter to the JB hypoxic region generally results from enhancement of algal production by high nutrient input, especially during the summer (i.e., phase II), from adjacent land (Lim et al., 2007, 2012; Jang P. G. et al., 2011; Kim et al., 2013a). Surface concentrations of dissolved inorganic nitrogen (DIN) and dissolved inorganic phosphorus (DIP) ranged to $0.3-22.0 \mu \mathrm{M}$ and $0.1-0.9 \mu \mathrm{M}$, respectively, though spatially inhomogeneous distribution (Kim S.-Y. et al., 2012). Chlorophyll-a concentrations in the surface water are somewhat higher $\left(\sim 2.5-25 \mu \mathrm{g} \mathrm{L}^{-1}\right)$ in the summer compared to the other seasons $\left(\sim 1.0-12 \mu \mathrm{g} \mathrm{L}^{-1}\right)$ (Kim et al., 2013a). Monthly primary productivity measured at 13 stations in 2008 ranged to 
238-1142 $\mathrm{mg} \mathrm{C} \mathrm{m}^{-2} \mathrm{~d}^{-1}$, with the highest in June (NIFS, 2012). The measurements near the Gajo Island in 2015 showed similar range (51-929 $\mathrm{mg} \mathrm{C} \mathrm{m}^{-2} \mathrm{~d}^{-1}$ ) and pattern peaked in June as well (Park, 2016). Values of stable carbon $(C)$ isotope $\left(\delta^{13} \mathrm{C}\right)$ measured in the water-column particulate organic matter (POM) in the Masan Bay during the period of 1991-1993 ranged from -15.4 to $-21.4 \%$ (mean: $-17.8 \%$ ), suggesting that marine sources (i.e., autochthonous characteristic) were dominant relative to terrestrial sources (i.e., allochthonous characteristic; Kim et al., 1994). Bae et al. (2017) also reported that total organic carbon contents having a $\mathrm{C} / \mathrm{N}$ ratios of between 6 and 8 were enriched (ca. 2.0-2.5\%) in the JB sediments, indicating delivery of surface organic matters formed by algal production to the sediments. In addition, the autochthonous POMs $\left(\mathrm{C} / \mathrm{N}\right.$ ratio: 8 and $\delta^{13} \mathrm{C}$ : $-18.8 \%$ ) in the upper most core sediments collected near the Gajo Island were dominant (Lim et al., 2012). However, there still remains further qualitative and quantitative investigation about the contribution of allochthonous and autochthonous POMs to hypoxia dynamics in the JB.

The JB oxygen consumption rates in bottom-water and sediment during Phase I and II ranged to 8-21 $\mathrm{mmol} \mathrm{O}_{2} \mathrm{~m}^{-3}$ $\mathrm{d}^{-1}$ and 2-30 mmol O $\mathrm{m}^{-2} \mathrm{~d}^{-1}$, respectively (Figure 3), which are comparable to those in the northern Gulf of Mexico (bottomwater: 4-11 mmol $\mathrm{O}_{2} \mathrm{~m}^{-3} \mathrm{~d}^{-1}$ and sediment: 4-20 mmol $\mathrm{O}_{2}$ $\mathrm{m}^{-2} \mathrm{~d}^{-1}$ from Murrell and Lehrter, 2011). The rate of bottomwater oxygen consumption was much higher in July $(21 \mathrm{mmol}$ $\left.\mathrm{O}_{2} \mathrm{~m}^{-3} \mathrm{~d}^{-1}\right)$ than in April $\left(8 \mathrm{mmol} \mathrm{O}_{2} \mathrm{~m}^{-3} \mathrm{~d}^{-1}\right)$ and positively correlated with bottom-water temperature $\left(r^{2}=0.95\right.$; based on the observations during April-September 2015; Lee et al., 2017), suggesting that increasing temperature may have stimulated microbial activity in the bottom waters. However, the rate of sediment oxygen consumption was much lower in summer $(2$ mmol $\left.\mathrm{O}_{2} \mathrm{~m}^{-2} \mathrm{~d}^{-1}\right)$ than in spring $\left(22 \mathrm{mmol} \mathrm{O} \mathrm{m}^{-2} \mathrm{~d}^{-1}\right)$ and showed strong dependence on oxygen availability $\left(r^{2}=\right.$ 0.70 ), indicating that sediment oxygen consumption may have inhibited by low oxygen availability due to hypoxia formation (Lee et al., 2017) as reported in other hypoxic zones (Kemp et al., 1992; Rowe et al., 2002; Murrell and Lehrter, 2011). These results suggest that both of bottom-water and sediment oxygen demands play important role in hypoxia development during phase I, accounting for each $50 \%$ of total oxygen consumption (i.e., bottom-water + sediment oxygen demands). In the meantime, bottom-water oxygen demands (i.e., accounting for $90 \%$ of total oxygen consumption) are more important for the persistence of hypoxia during phase II (Lee et al., 2017). These findings were derived from incubated-experiment results. Therefore, a further research, based on in-situ experiment (such as chamber incubation), is needed to fully understand dynamics of oxygen demands in the bottom water and sediment.

\section{Biogeochemical and Ecological Responses}

A significant undesirable consequence of coastal hypoxia is the disturbance of the marine biogeochemical cycles that control nutrient composition and carbonate chemistry in the marine ecosystem (Conley et al., 2002; Middelburg and Levin, 2009; Cai et al., 2011). The ratio of DIN to DIP in the JB bottom waters in the summer was estimated to be $<\sim 10$ in 2016
(NIFS, 2017), indirectly indicating influence of $\mathrm{N}$ sink and/or P source processes. Hypoxic conditions are potentially favorable for $\mathrm{N}$ removal processes, such as denitrification (i.e., $\mathrm{NO}_{3}^{-} \rightarrow$ $\mathrm{NO}_{2}^{-} \rightarrow \mathrm{N}_{2} \mathrm{O} / \mathrm{N}_{2}$ ) and anaerobic ammonium oxidation (i.e., $\mathrm{NH}_{4}^{+}+\mathrm{NO}_{2}^{-} \rightarrow \mathrm{N}_{2}$ ), in marine environments (Christensen et al., 1990; Seitzinger and Giblin, 1996). Of N sink processes, denitrification is responsible mainly for the loss of reactive $\mathrm{N}$ in coastal benthic systems (Dalsgaard et al., 2005), leading to Nlimited conditions. The potential benthic denitrification rate in JB was measured directly using a ${ }^{15} \mathrm{~N}$ isotope technique, and was found to range from 1 to $31 \mu \mathrm{mol} \mathrm{N} \mathrm{m}{ }^{-2} \mathrm{~h}^{-1}$ (MOF, 2016), which is comparable to values obtained in other hypoxic coastal regions, including the Baltic Sea, Chesapeake Bay, and Adriatic Sea, which ranged from 6 to $37 \mu \mathrm{mol} \mathrm{N} \mathrm{m}{ }^{-2} \mathrm{~h}^{-1}$ (Tuominen et al., 1998; Voss et al., 2005; Gustafsson and Stigebrandt, 2007), 1 to $26 \mu \mathrm{mol} \mathrm{N} \mathrm{m}{ }^{-2} \mathrm{~h}^{-1}$ (Kemp et al., 1990), and 1 to $48 \mu \mathrm{mol}$ $\mathrm{N} \mathrm{m}^{-2} \mathrm{~h}^{-1}$ (Degobbis et al., 1986), respectively. Under hypoxic conditions, substantial amounts of DIP can be released from sediments via desorption of iron-bound P (Jensen et al., 1995; Conley et al., 2002; Howarth et al., 2011). Kim S.-Y. et al. (2012) reported that bottom-water DO concentrations are correlated significantly with DIP concentrations during the hypoxic season in the JB $(r=-0.67, p<0.001)$, resulting from the combination of an increased DIP flux from sediment and accumulation in the bottom layer due to strong stratification. As a result, an additional DIP source may contribute to the lowering of the DIN:DIP ratio in the bottom waters of JB (Jang P. G. et al., 2011; Kim S.-Y. et al., 2012; Kim et al., 2013a). However, there is little information about whether the low DIN:DIP ratio in the JB bottom-water is mainly derived by $\mathrm{N}$ sink or $\mathrm{P}$ source processes, so further research is needed.

An extremely high DIN:DIP ratio (110) is maintained in the JB surface water during summer due to $\mathrm{N}$-dominated eutrophication (Kim et al., 2013a; Kim Y.-S. et al., 2015), indicating that $\mathrm{P}$ may be a limiting element for phytoplankton growth. In general, surface DIP is extremely scarce during summer due to strong stratification, and accumulated bottomwater DIP is the major source (Kim Y.-S. et al., 2015). As a result, the bottom-water DIP has been found to make an important contribution to surface primary production in JB when stratification becomes weak (Kim Y.-S. et al., 2015). For example, in phase III (September-October), when active vertical mixing begins to occur, the surface DIN:DIP ratio is reduced to 16 and the chlorophyll-a concentration is $14 \mu \mathrm{g} \mathrm{L}^{-1}$, i.e., higher than in phase II $\left(9 \mu \mathrm{g} \mathrm{L}^{-1}\right)$ (Kim Y.-S. et al., 2015). The bottomwater hypoxia has resulted in a severe imbalance in the DIN:DIP ratio between surface (i.e., P-limited condition) and bottom (i.e., $\mathrm{N}$-limited condition) waters in the JB.

Low oxygen conditions are also accompanied by a decrease in $\mathrm{pH}$, which results from $\mathrm{CO}_{2}$ production via the decomposition of organic matters by microbial respiration (Cai et al., 2011; Melzner et al., 2013). During phase II, the bottom-water $\mathrm{pH}$ values measured in summer 2010 ranged from 6.6 to 8.2 (mean, $7.6 \pm 0.2$ ), and the bottom-water $\mathrm{pH}$ was correlated significantly with the bottom-water DO $(r=0.9, p<0.001)$ in the JB (Kim S.-Y. et al., 2012). In addition, the level of aragonite saturation $\left(\Omega_{\text {ara }}\right)$ in the bottom waters was much lower in summer $\left(\Omega_{\text {ara }}\right.$ 
$=1.2$ ) than the other seasons $\left(\Omega_{\text {ara }}=2.2-2.5\right.$; Kim et al., $2013 \mathrm{~b})$. These findings suggest that bottom-water hypoxia in JB is linked to the problem of coastal acidification (Kim S.Y. et al., 2012; Kim et al., 2013b), which potentially damages calcareous organisms due to the dissolution of calcium carbonate by the reduction of carbonate saturation (Gazeau et al., 2007; Cai et al., 2011). As shown in Figure 4, the rapid expansion of the hypoxic area in JB in summer may have a negative impact on the growth of calcareous-shelled organisms, such as edible mussel (Mytilus edulis) and Pacific oyster (Crassostrea gigas), which are economically important organisms in the JB aquaculture industry (Kim et al., 2013b). However, no study has examined the direct effect of the relationship among bottom-water hypoxia, acidification, and calcification on the JB ecosystem in detail; such research is urgently needed.

Because many benthic organisms are sessile, benthic communities are especially susceptible to bottom-water hypoxia (Vaquer-Sunyer and Duarte, 2008; Levin et al., 2009). Lim et al. (2006) investigated the seasonal variation in benthic community structure along a section extending from Masan Bay to the Gadeok Channel (Sts. 1-4 in Figures 2, 5). Because bottom-water hypoxia developed and persisted during summer at Sts. 1 and 2, which lie in an area that experiences chronic bottom-water hypoxia (numbers of $\mathrm{HO} \geq 13$; Figure 2), the number of species, abundance, and diversity (Shannon diversity index) were found to be almost null, indicating massive mortality of benthic fauna during summer. The damage to the benthic community persisted until October, despite the disappearance of bottom-water hypoxia. The benthic community recovered slowly, with lag times of 1-4 months (Figure 5). The first recruitment in JB generally began from opportunistic species, such as the polychaete Paraprionospio pinnata and the bivalve Terestrombus fragilis (Lim et al., 2006), which are known to be relatively resistant to low oxygen levels (Boesch and Rabalais, 1991; Tamai, 1993). During fall and winter, the number of species, abundance, and diversity increased to $\sim 30$ species $0.5 \mathrm{~m}^{-2}, \sim 800$ individuals $\mathrm{m}^{-2}$, and $\sim 3$, respectively, and the recovery of the benthic community was sustained until the following spring (Figure 5). Therefore, severe hypoxia during summer clearly caused a high degree of mass mortality and the slow recolonization of benthic fauna in the JB ecosystem.

\section{HYPOXIA IN THE ARTIFICIAL SYSTEM OF SB}

\section{General Characteristics}

$\mathrm{SB}$ is located on the western coast of South Korea, and is an artificial bay isolated by a dyke, with an area of $56.5 \mathrm{~km}^{2}$ and a mean depth of $3.2 \mathrm{~m}$. As part of a government land reclamation project conducted during the 1980s and 1990s, Shihwa Dyke (12.7 km long, with a $100-\mathrm{m}$ sluice gate) was built in the mouth of the Shihwa Estuary in 1994, creating a large artificial lake (called "Lake Shihwa") to supply water for agricultural and industrial purpose, and to extend the area of agricultural land (173 $\mathrm{km}^{2}$ reclaimed land; Bae et al., 2010; Lee et al., 2014). However, the artificial dyke was built without consideration of the surrounding environmental conditions, including the lack of wastewater treatment facilities and massive nutrient loading from neighboring industrial complexes and large cities (e.g., Ansan, Shiheung, and Hwaseong), and the restricted water circulation resulted in a rapid deterioration of water quality (Park et al., 1997, 2003). For example, the chemical oxygen demand (COD), an index used to assess the magnitude of organic pollution, exceeded $\sim 17 \mathrm{mg} \mathrm{L}^{-1}$ in the water-column in 1997 (after construction of the dyke), which was approximately six times higher than before the dyke was built ( $\sim 3 \mathrm{mg} \mathrm{L}^{-1}$ in 1993; Lee et al., 2014). Since the isolation, reports have also documented black coloration and unpleasant odor of the seawater, and massive fish kills have occurred in the eutrophic lake (Cho, 2005).

To improve the water quality, the government revised the original plan, which involved desalination of the bay water by preventing mixing with seawater, to partial exchange via a small gate. Since July 1997, the bay water has again been allowed to mix with seawater entering via the sluice gates, and this exchange has been allowed to occur regularly since March 1999. In addition, the government has taken various other measures, such as the enhancement of sewage treatment systems and installation of a total pollution load management system (Bae et al., 2010). As a result, water quality has improved; for example, the COD decreased from $\sim 17 \mathrm{mg} \mathrm{L}^{-1}$ in 1997 to $\sim 4.5 \mathrm{mg} \mathrm{L}^{-1}$ in 2001 (Lee et al., 2014). Nevertheless, large amounts of anthropogenic $\mathrm{N}$ are still discharged, mainly through a number of stream runoffs, into the sluggish $\mathrm{SB}$, with the main sources being domestic sewage $\left(5,400 \mathrm{~kg} \mathrm{day}^{-1}\right)$, land-used waste $(3,000 \mathrm{~kg}$ $\left.\mathrm{day}^{-1}\right)$, and industrial effluents $\left(2,700 \mathrm{~kg} \mathrm{day}^{-1}\right)$. The SB still suffers from chronic environmental problems, including red tides and bottom-water hypoxia and anoxia, more than two decades later (Park et al., 1997; Hwang, 2008; Yoo, 2010; Kang N. S. et al., 2013a).

\section{Temporal and Spatial Distribution of Hypoxia}

The bottom-water hypoxia in SB is currently a seasonal phenomenon, occurring during summer (mostly JuneSeptember; Figures 6, 7; Hwang, 2008; Yoo, 2010). The seasonal variation in bottom-water oxygen is associated closely with stream runoff, and is determined by physical and biogeochemical factors (MOF, 2009; Yoo, 2010). Until April, bottom-water DO concentrations are in the range of $8-14 \mathrm{mg} \mathrm{L} \mathrm{L}^{-1}$, indicating a sufficient oxygen supply. Lower concentrations of bottom-water DO $\left(5 \mathrm{mg} \mathrm{L}^{-1}\right)$ are observed with increasing $\Delta \mathrm{T}$ (up to $5^{\circ} \mathrm{C}$ ) in May, but the variation in $\Delta S$ is small $(0-2)$ due to the low freshwater discharge, indicating the enhancement of thermal stratification. The bottom-water hypoxic conditions in SB generally appear in June and persist until September, accompanied by high $\Delta S$ (5-15) and chlorophyll-a concentrations (20-90 $\left.\mu \mathrm{g} \mathrm{L}^{-1}\right)$. The hypoxic conditions are usually terminated in October, when the water-column thermal and/or haline stratification begins to weaken, which permits the exchange of oxygen-rich surface water with hypoxic bottom-water. 


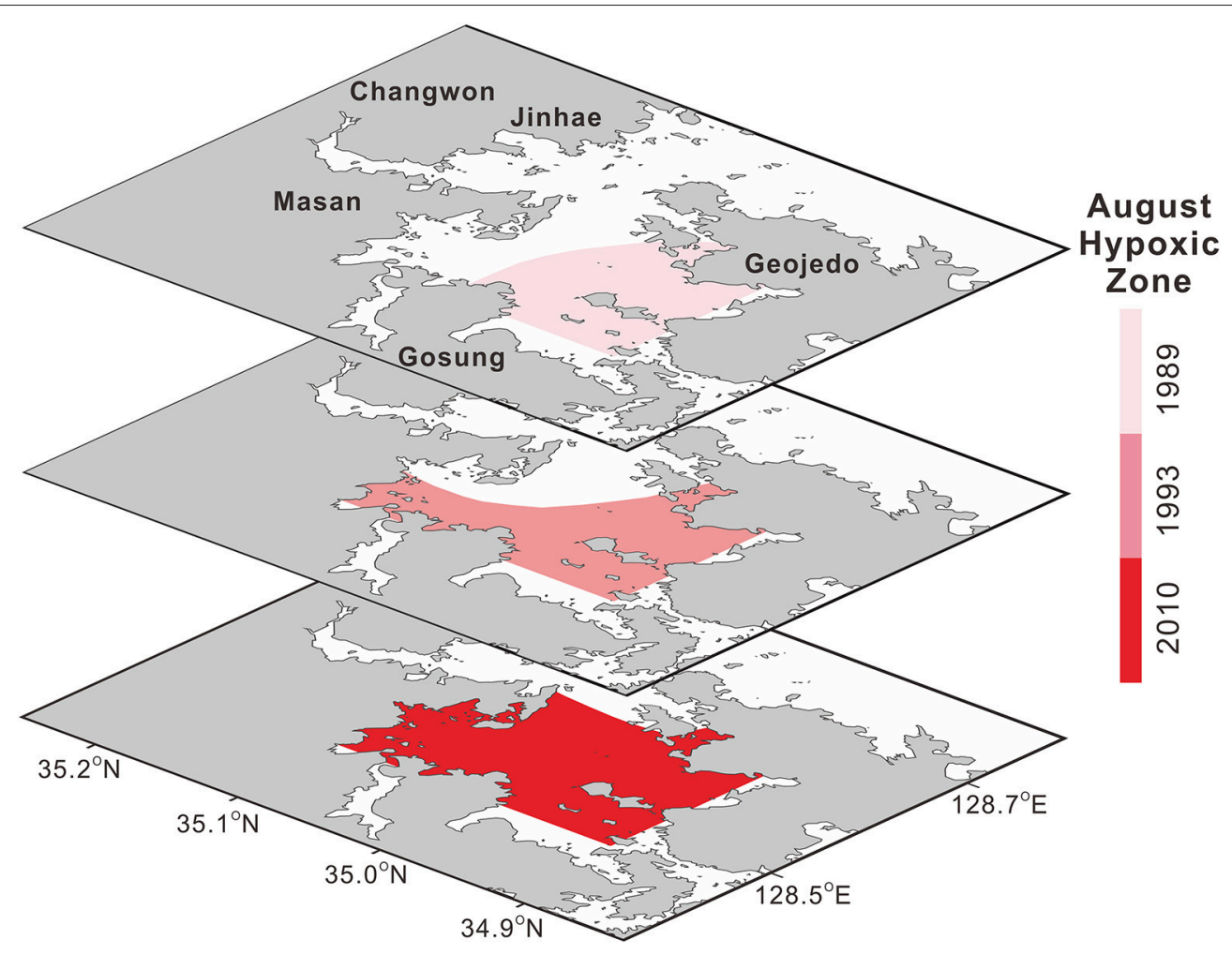

FIGURE 4 | Decadal variation in the areal extent of summer (August) hypoxia in Jinhae Bay (shown for 1989, 1993, and 2010). Sources: Modified from Kim and Lee (1994). Reproduced with permission of the Korean Society of Fisheries and Aquatic Science, Modified from Lim et al. (2006), and Modified from Kim S.-Y. et al. (2012). Reproduced with permission of the Korean Society of Nature Conservation.

The spatial distribution of hypoxic bottom-water is also subject to seasonal variation. Hypoxic (i.e., equivalent to $\mathrm{O}_{2}$ saturation $<30 \%$ ) bottom-water appears in June in the area off the Shihwa-Banwol industrial complex (Figure 7), where water is extremely stagnant, and then extends to a large area of the SB until August. Most bottom-water in SB becomes hypoxic during summer, and even suboxic $\left(\mathrm{O}_{2}\right.$ saturation $\left.<\sim 10 \%\right)$ water has been found in the central region of $\mathrm{SB}$, which has a relatively higher content of total organic carbon in its sediment $(1.6 \%)$ compared to the mean value $(1.3 \%)$ averaged from the entire area (MOF, 2009).

SB has been transformed anthropogenically from an open, natural bay system (before 1994) to an artificial lake system (1994-1997; "desalination era"), and finally to an enclosed artificial bay system (after 1997; Figure 8). The bottom-water DO has been influenced directly by artificial modifications over the last two decades (Figure 8A). For example, observational data collected from March to November 1993 showed that the bottom-water DO concentration ranged from 5.9 to $8.8 \mathrm{mg} \mathrm{L}^{-1}$, indicating active vertical mixing, before the construction of the dyke (Hwang, 2008). After the dyke had been completed, the bottom-water rapidly became hypoxic or suboxic during the desalination era. The mean bottomwater DO concentration was $7.7 \mathrm{mg} \mathrm{L}^{-1}$ (range, $6.5-8.8 \mathrm{mg}$ $\mathrm{L}^{-1}$ ) in the first year of dyke construction (1994). In the second year, it was $3.0 \mathrm{mg} \mathrm{L}^{-1}$ (range, $0.5-4.7 \mathrm{mg} \mathrm{L}^{-1}$ ), and hypoxia appeared in August 1995 for the first time. In the third year, the mean bottom-water DO concentration was $0.9 \mathrm{mg} \mathrm{L}^{-1}$ (range, $0.2-3.8 \mathrm{mg} \mathrm{L}^{-1}$ ), with suboxic conditions reached in August 1996 (Figure 8A). The period of hypoxia increased two-fold, i.e., from 4 months (August-November) in 1995 to 8 months (April-December) in 1996 (Choi, 2001).

Since July 1997, seawater has been allowed to enter SB via the sluice gate, enabling recirculation of SB water. The amount of seawater exchange increased gradually after 1999; the mean bottom-water DO concentration in spring and fall in 2000 increased to $8.7 \mathrm{mg} \mathrm{L}^{-1}$, compared with $0.5 \mathrm{mg} \mathrm{L}^{-1}$ for the same period in 1996 (Figure 8A). However, regardless of the seawater exchange rate, the bottom-water DO concentration declined to hypoxic levels in summer from 1997 to the late 2000s (Figures 68; Park et al., 1997, 2003; MOF, 2009, 2010; NIFS, 2009).

A tidal power plant (TPP) was built on the Shihwa Dyke and has been operational since 2012. The rate of seawater inflow after the plant had been completed has increased 5.6-fold compared with the period before its construction (i.e., from 250 to 1570 million tons day ${ }^{-1}$; Lee, 2017). Ra et al. (2013) reported that the mean bottom-water DO saturation value during July and August increased as a consequence from 52\% (range, 3-154\%) in 2011 to $96 \%$ (range, 55-150\%) in 2012 . However, whether the 


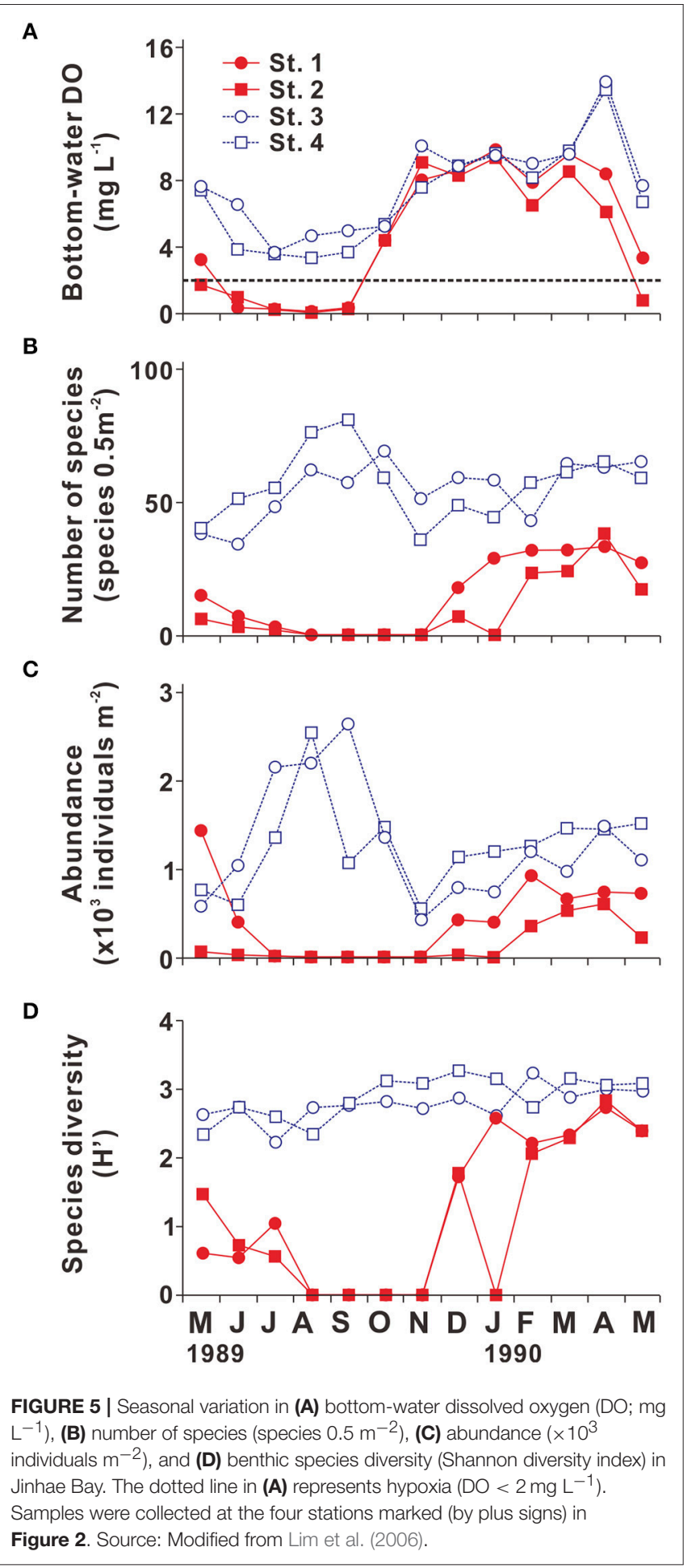

bottom-water hypoxia in SB has persisted or disappeared is not known because detailed monitoring surveys were halted in 2012.

\section{Factors Controlling Bottom-Water Hypoxia}

Artificial coastal structures, such as dykes and dams, alter water circulation and biogeochemical cycling in coastal regions by interrupting the natural exchange between seawater and freshwater (Gedan et al., 2009). A lack of circulation results in high degrees of accumulation of organic matter in water and sediment, and strong water-column stratification (Portnoy, 1991), which favor the development of hypoxia.

Before the dyke was completed, the tidal range on the Shihwa coast was more than $\sim 10 \mathrm{~m}$, which was one of the largest tidal ranges in the world's oceans (Frey et al., 1989; Cho, 2005), indicating strong tidal mixing. Large amounts of anthropogenic pollutants (e.g., nutrients, heavy metals, and organic contaminants) from adjacent streams have been discharged into the Shihwa coastal region due to inadequate sewage treatment systems, but their accumulations were small due to strong tidal mixing. As a result, the bottom-water contained sufficient DO in summer and the Shihwa was not considered to be a hypoxic coastal region (Han and Park, 1999; Hwang, 2008).

During 1994-1997 (i.e., the desalination era), SB was created by the construction of a dyke on the coast. This construction resulted in a relatively small enclosed coastal area of $47.7 \mathrm{~km}^{2}$ and a total volume of 330 million tons, with a freshwater discharge of $\sim 340$ million tons year $^{-1}$ (Lee et al., 2014). It has caused a substantial increase in the residence time of water and contaminants, leading to severe eutrophication and occurrence of bottom-water hypoxia in SB (Han and Park, 1999). For example, water-column total N measured in 1995 $(\sim 320 \mu \mathrm{M})$ was five times higher than that measured during 1991-1993 ( $\sim 60-80 \mu \mathrm{M})$ (Cho, 2005). In addition, the annual mean chlorophyll-a concentration and primary productivity were estimated to be $169 \mu \mathrm{g} \mathrm{L}^{-1}$ and $3,972 \mathrm{mg} \mathrm{C} \mathrm{m}^{-2}$ day $^{-1}$, respectively, in 1995, $\sim 90$ times higher than the corresponding values in 1993 (during the dyke construction; Choi et al., 1997). The surface- and bottom-water COD values also increased remarkably from 3.9 and $1.7 \mathrm{mg} \mathrm{L}^{-1}$, respectively, in 1994 to 9.8 and $12.5 \mathrm{mg} \mathrm{L}^{-1}$, respectively, in 1996 (Figures 8D,E), indicating an increase in the organic matter content in the water-column. Moreover, water-column stratification became much stronger during the desalination era, with increases in the mean $\Delta \mathrm{T}$ and $\Delta \mathrm{S}$ during the spring to fall seasons (i.e., March-November) from $0.3^{\circ} \mathrm{C}$ and 0.1 , respectively, in 1994 to $7.2^{\circ} \mathrm{C}$ and 4.7 , respectively, in 1996. The maximum $\Delta S$ reached 17.6 in fall 1995 due to large freshwater input (Figure 8B).

After summer 1997, water in SB was partially recirculated via a sluice gate, which enabled seawater exchange. As haline stratification and COD declined, the water quality gradually improved (Figures 8B,D). However, seawater exchange (plus additional efforts such as the expansion of public treatment facilities) was insufficient to dissipate the hypoxia in SB (Lee et al., 2014). In Figure 6, peak of $\Delta S$ coincides with the period of lowest value of DO in every summer (yellow shaded area). In addition, Yoo (2010) reported negative correlation between salinity and chlorophyll-a concentration $(r=-0.6, p<0.01)$ and particulate organic carbon (POC) $(r=-0.6, p<0.01)$ as well as positive correlation between chlorophyll-a concentration and POC $\left(r^{2}\right.$ $=0.8, p<0.01)$, indicating enhancement of phytoplanktonderived organic matter by high nutrient inputs from freshwater discharge. These findings indicate that strong haline stratification 


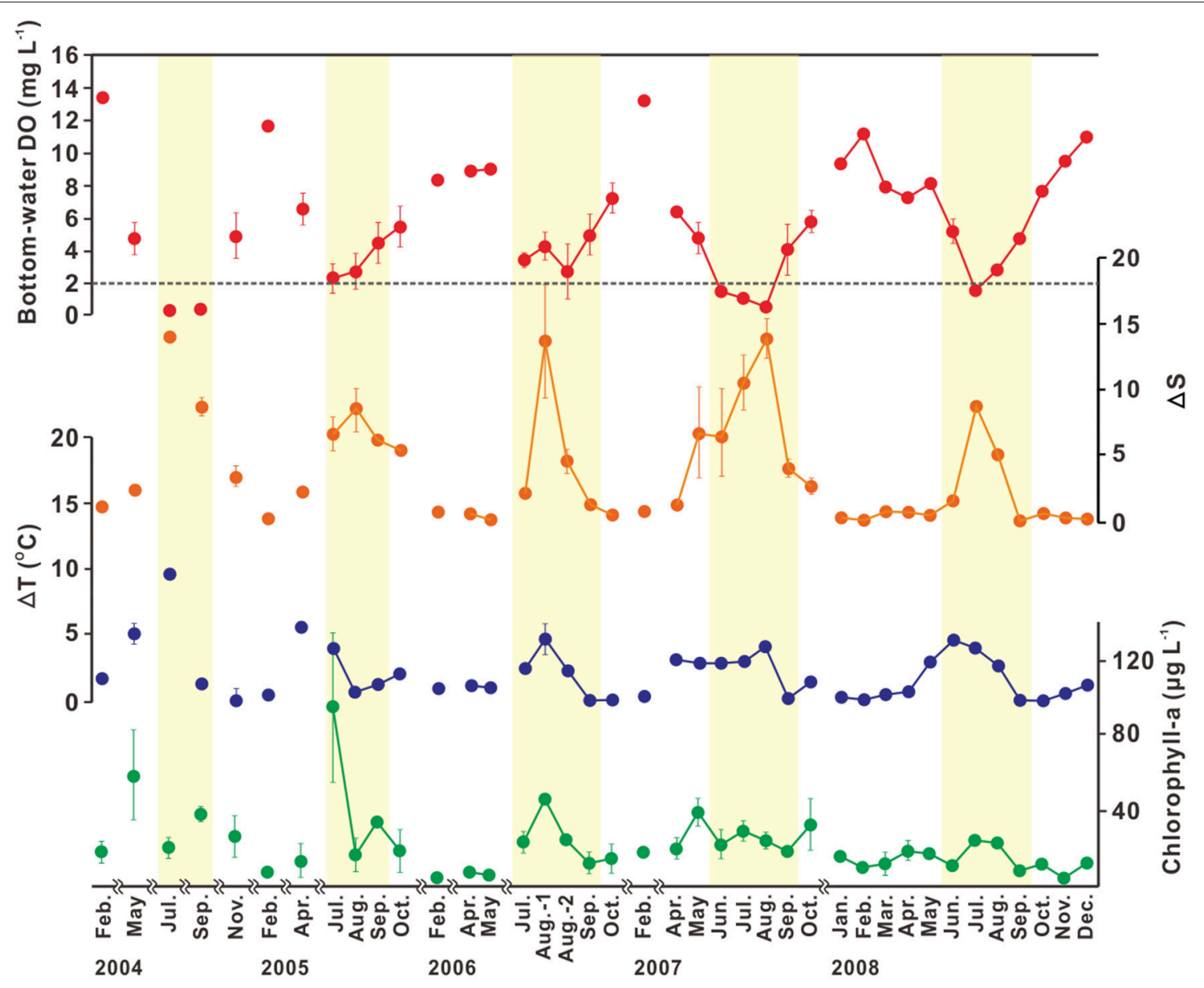

FIGURE 6 | Temporal variation in bottom-water dissolved oxygen ( $\mathrm{DO} ; \mathrm{mg} \mathrm{L}^{-1}$ ), $\Delta \mathrm{S}$ (i.e., the difference between surface and bottom salinity), $\Delta \mathrm{T}$ (i.e., the difference between surface and bottom temperatures; ${ }^{\circ} \mathrm{C}$ ), and surface chlorophyll-a concentration ( $\mu \mathrm{g} \mathrm{L}^{-1}$ ) observed during 2004-2008 in Shihwa Bay. Error bars indicate the standard deviations from the mean. The dotted line in bottom-water dissolved oxygen represents hypoxia $\left(\mathrm{DO}<2 \mathrm{mg} \mathrm{L}^{-1}\right)$. Yellow shaded areas indicate hypoxic period from June to September. Source: Modified from Yoo (2010). Used with permission.

and high levels of autochthonous production due to freshwater discharge contribute to the onset and persistence of hypoxia in SB until the late 2000s (MOF, 2010; Yoo, 2010), as seen in Chesapeake Bay and the Gulf of Mexico (Kemp et al., 1992; Rivera et al., 2010). Since March 2012, the operation of the Shihwa TPP has increased the seawater exchange rate, resulting in a slight recovery from bottom-water hypoxic conditions (Kang Y. S. et al., 2013b; Ra et al., 2013). Therefore, we need to investigate how the bottom-water hypoxia in SB has been changed since 2012 .

\section{Biogeochemical and Ecological Responses}

The presence of the dyke has significantly altered the SB ecosystem in terms of its biogeochemical properties and benthic community composition, due to the effects of anthropogenic isolation. Han and Park (1999) reported extremely high concentrations of ammonium $(\sim 450 \mu \mathrm{M})$, with rapid oxygen consumption in the halocline ( $\sim 6-8 \mathrm{~m}$ depth), measured during a hydrographic survey conducted in March 1996 (during the desalination era of 1994-1997); these findings indicate excessive accumulation of reduced $\mathrm{N}$ in the bottom-water.
Bottom-water hypoxia was distributed widely during summer 1997 (Figure 8), together with high ammonium (27.2-628.5 $\mu \mathrm{M}$ ) and low nitrate (1.5-2.7 $\mu \mathrm{M})$ concentrations (Park et al., 2003). Accumulation of ammonium and deficiency of nitrate indirectly indicate inhibition of the coupled nitrification (i.e., $\mathrm{NH}_{4}^{+} \rightarrow$ $\mathrm{NO}_{2}^{-} \rightarrow \mathrm{NO}_{3}^{-}$)-denitrification (i.e., $\mathrm{NO}_{3}^{-} \rightarrow \quad \mathrm{NO}_{2}^{-} \rightarrow$ $\mathrm{N}_{2} \mathrm{O} / \mathrm{N}_{2}$ ) processes under hypoxic condition in the $\mathrm{SB}$, which is contradictory to the JB (refer section Biogeochemical and Ecological Responses). Denitrification is largely dependent on nitrate availability, so hypoxic condition may show different features (Kemp et al., 1990; Childs et al., 2002; Conley et al., 2009b). However, there is little information about direct denitrification activity in the SB, so a research on this topic is needed. In addition, excessive accumulation of phosphate (3.4$50.9 \mu \mathrm{M}$ ) (Han and Park, 1999; Park et al., 2003), resulting from the substantial release of iron-bound $\mathrm{P}$ from sediment (Gächter and Meyer, 1993), was found in the hypoxic bottomwater. In March 1996, significantly elevated $\mathrm{H}_{2} \mathrm{~S}(\sim 45 \mu \mathrm{M})$ (Han and Park, 1999), which is toxic to benthic organisms (Diaz and Rosenberg, 1995; Gamenick et al., 1996), was observed in the 


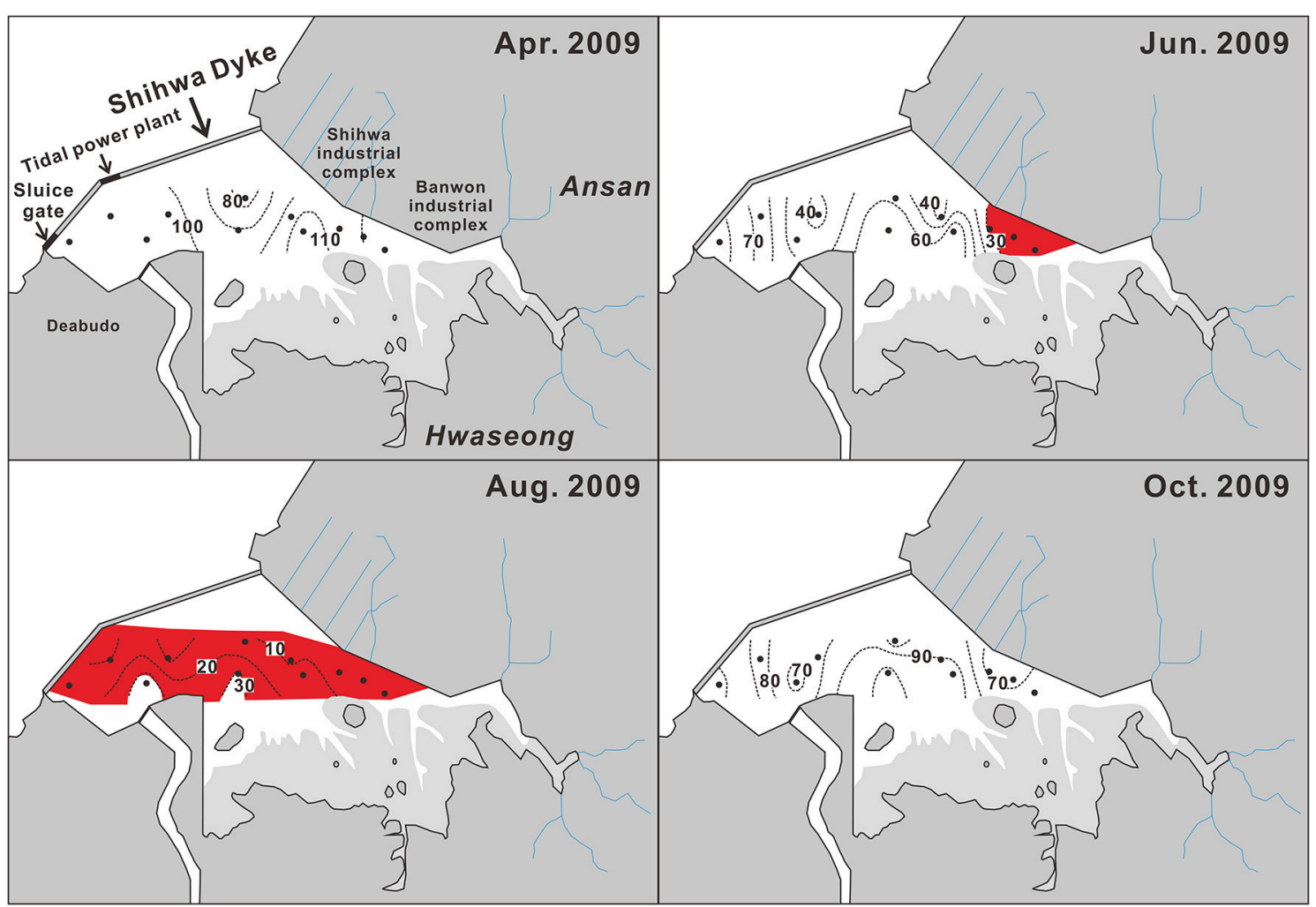

FIGURE 7 | Seasonal spatial distribution of bottom-water dissolved oxygen saturation (\%) observed in 2009 in Shihwa Bay. Red areas represent hypoxic water (oxygen saturation $<30 \%$ ). Black dots indicate sampling stations. The data source is the Ministry of Oceans and Fisheries report (2009).

hypoxic bottom-water in SB (Han and Park, 1999). In the marine environment, $\mathrm{H}_{2} \mathrm{~S}$ is produced mainly by sulfate reduction, which is a type of anaerobic respiration (Canfield et al., 1993). In addition, a low $\mathrm{pH}$ value $(\sim 6.8)$, indicating "coastal acidification" that may threaten $\mathrm{CaCO}_{3}$-shelled benthic organisms (Cai et al., 2011), was recorded in the hypoxic bottom-water (Han and Park, 1999). Therefore, bottom-water hypoxia during the desalination era contributed to acidification in the SB ecosystem (Han et al., 1997; Park et al., 1997, 2003; Han and Park, 1999).

Benthic communities in SB have been altered significantly by multiple factors (i.e., development of bottom-water as well as changes in circulation, salinity, eutrophication, and isolation) (Figure 9) (Hwang, 2008; Jung et al., 2012; Lee et al., 2014). Lee et al. (2003) investigated the total numbers of benthic faunal species in SB in three periods: before the dyke was built (1980), the early desalination period (1994-1995), and the late desalination period (1995-1996). The results revealed significant reduction in the total number of benthic faunal species over the three periods, from $\sim 110$ species $0.3 \mathrm{~m}^{-2}$ to $\sim 90$ species 0.3 $\mathrm{m}^{-2}$ to $\sim 40$ species $0.3 \mathrm{~m}^{-2}$. Furthermore, dominant benthic species, such as Notomastus species were no longer present in SB after the construction of the dyke (Lee and Khim, 2017); they were replaced by opportunistic species (Hong et al., 1997; Hwang, 2008), particularly polychaetes such as Pseudopolydora kempi and Polydora cornuta, which are known to live exclusively under eutrophic conditions (Pearson and Rosenberg, 1978). As a result, the species diversity index (i.e., Shannon index) declined rapidly from 1.9 during dyke construction (1993) to 0.7 after dyke construction (1994-1996) (Figure 9D). These ecosystem changes were attributed to the evolution of SB bottom-water hypoxia, from its appearance to settlement (Figures 8, 9; Hong et al., 1997; Ryu et al., 1997; Lee et al., 2003, 2014; Lee and Khim, 2017).

After the partial opening of the sluice gate (in 1997), which reintroduced water recirculation in $\mathrm{SB}$, the water exchange rates increased from $\sim 1,200$ million tons per year during 1997 to $\sim 9,000$ million tons per year after 1998 (Choi et al., 2008). Benthic community indexes, i.e., the number of species, abundance, and diversity increased gradually, particularly near the sluice gate (blue area in Figure 9A). Based on published data for a 20-year period, Lee and Khim (2017) reported that the abundance of some opportunistic species (e.g., Prionospio japonicus) in SB diminished after the partial gate opening, although some species (e.g., P. kempi and P. cornuta) remained dominant. These results indicate that the SB benthic community has recovered partially since 1997 . However, the bottom-water hypoxia occurring in summer due to insufficient water exchange and the input of large amounts of pollutants from inland still impacts the benthic community in SB (Hwang, 2008; Jung et al., 2012). For example, decreases in the number of species, abundance, and diversity of benthic fauna were observed in June and September in the inner area (Figures 9E-G). Therefore, a continuous long-term monitoring program is essential for accurate assessment of the effects of artificial structures on ecosystem changes in the bay. 


\section{A}

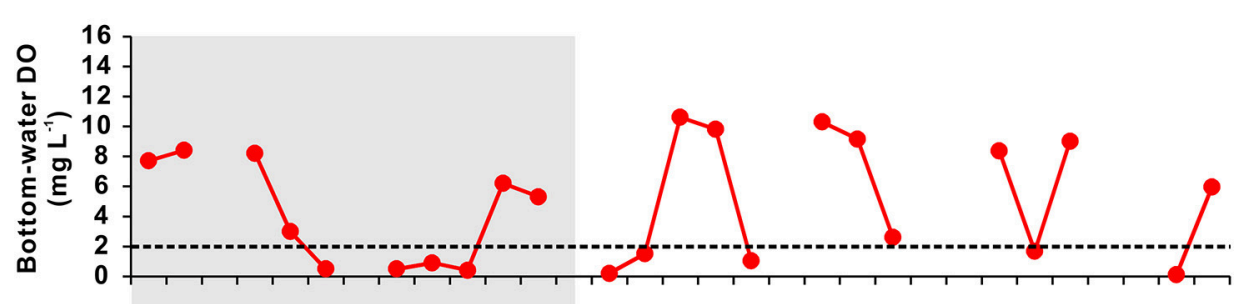

B

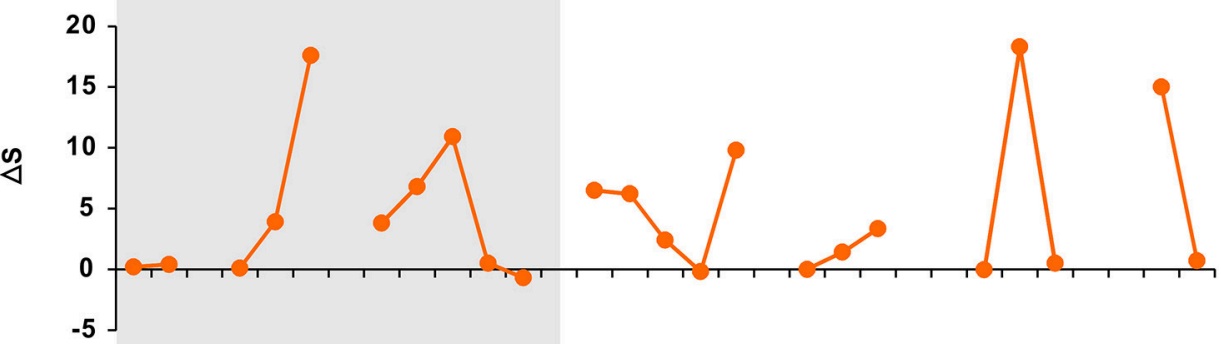

C

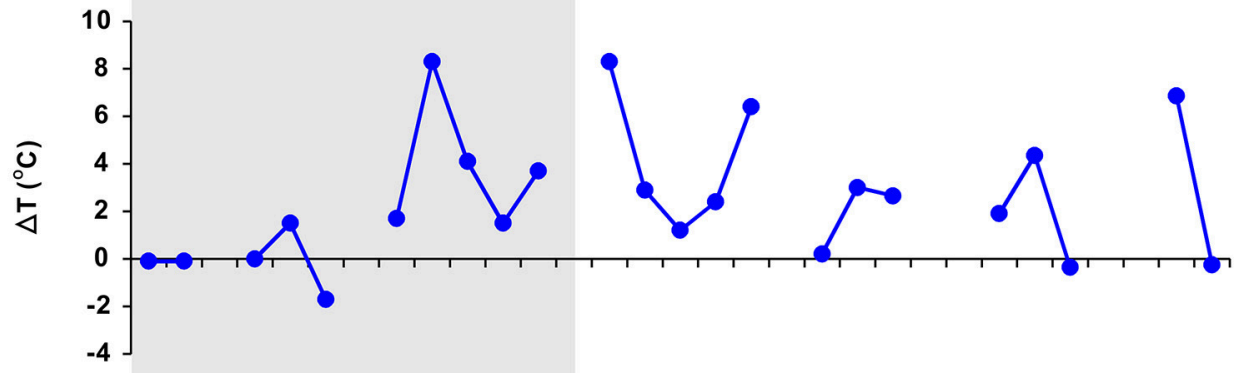

D

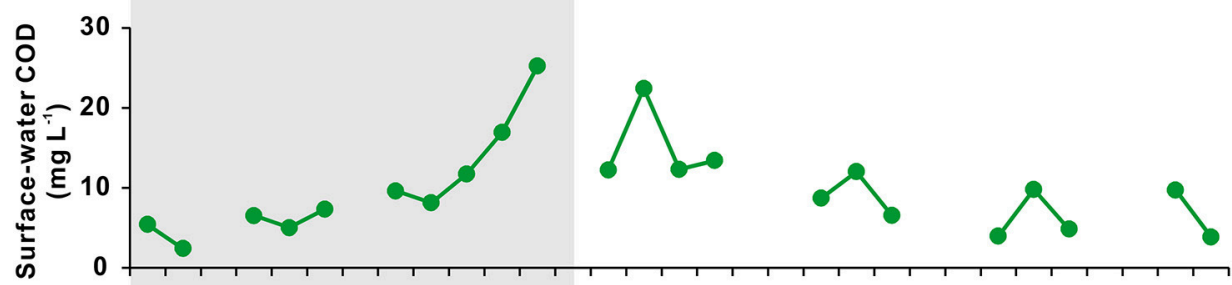

E

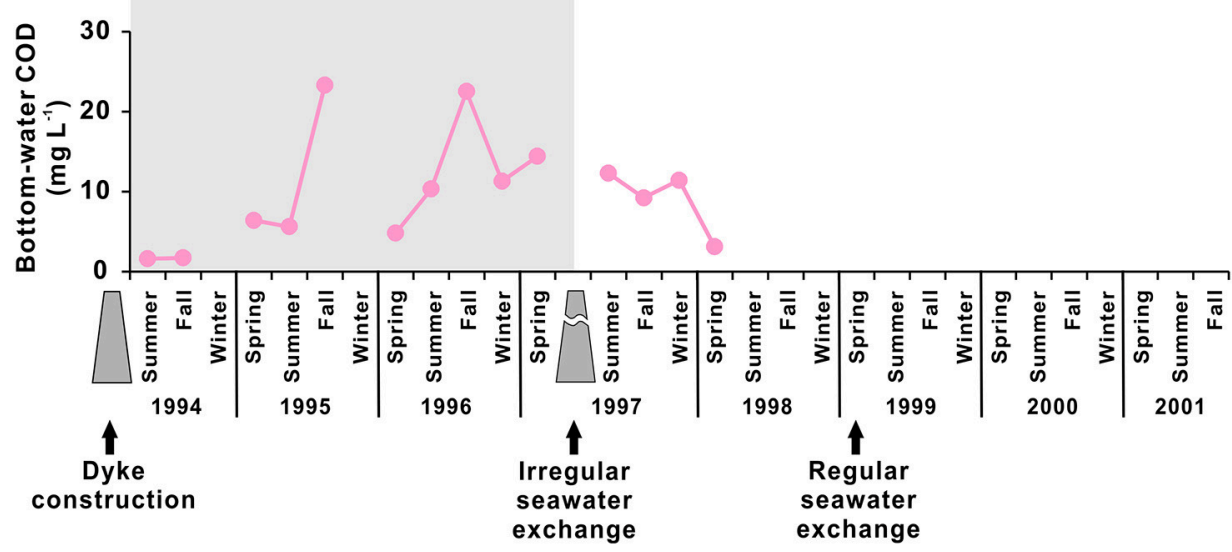

FIGURE 8 | Temporal variation in (A) bottom-water dissolved oxygen (DO; $\mathrm{mg} \mathrm{L}^{-1}$ ), (B) $\Delta \mathrm{S}$ (i.e., the difference between surface and bottom salinity), (C) $\Delta \mathrm{T}$ (i.e., the difference between surface and bottom temperatures; ${ }^{\circ} \mathrm{C}$ ), (D) surface chemical oxygen demand (COD; $\mathrm{mg} \mathrm{L}^{-1}$ ), and (E) bottom COD observed during $1994-2001$ in Shihwa Bay. The shaded area represents the period of desalination after construction of a dyke (i.e., 1994-1997). The dotted line in (A) represents hypoxia (DO < $2 \mathrm{mg} \mathrm{L}^{-1}$ ). The data sources are Choi (2001) and Park et al. (2003). 


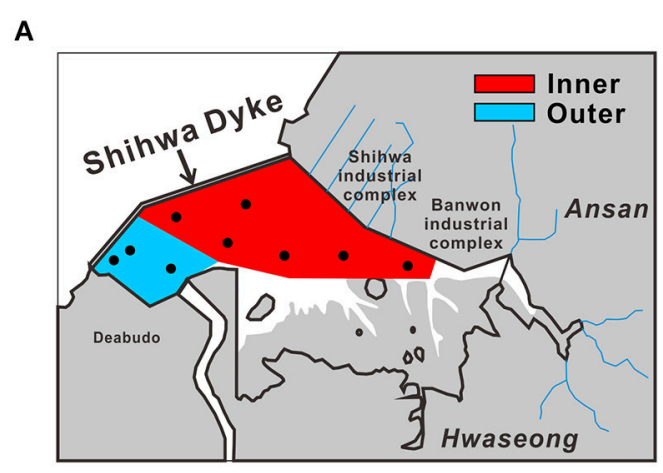

B

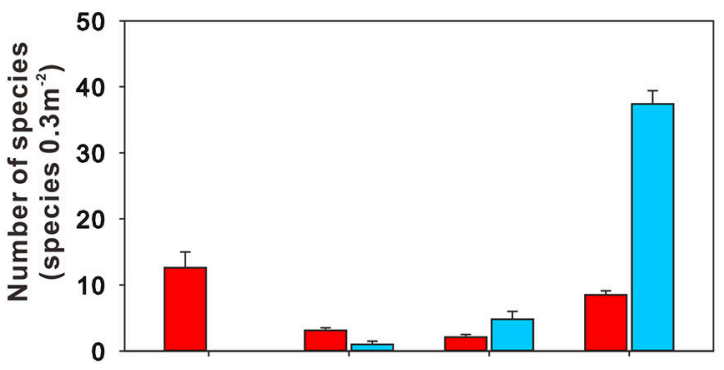

C

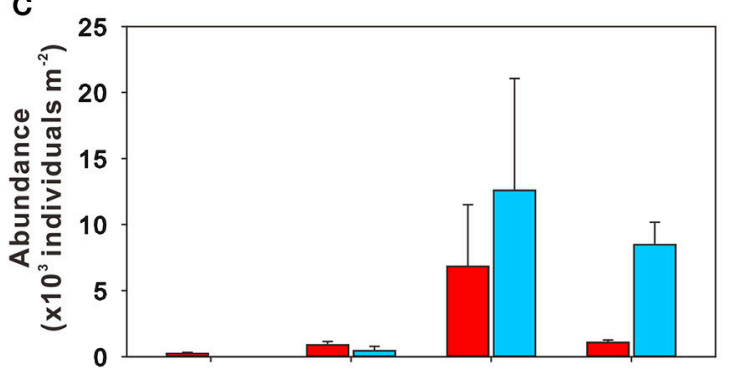

D

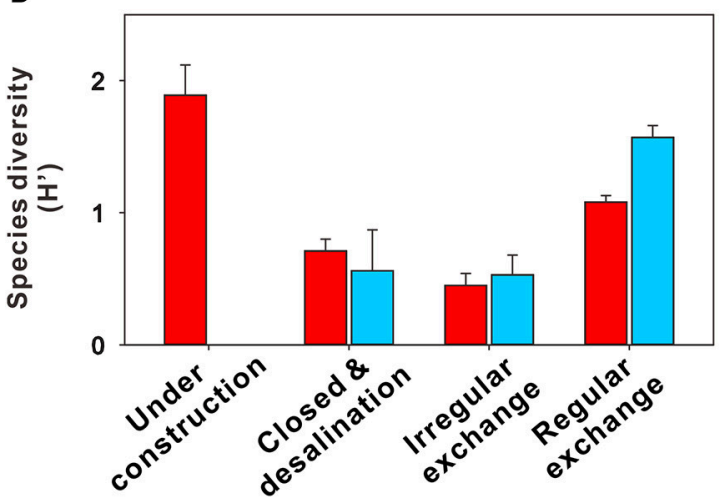

E

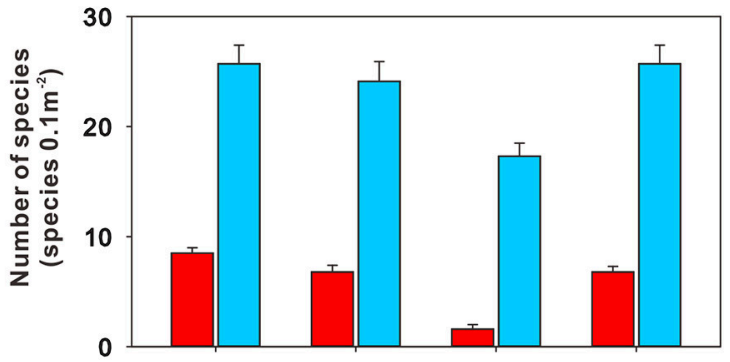

F

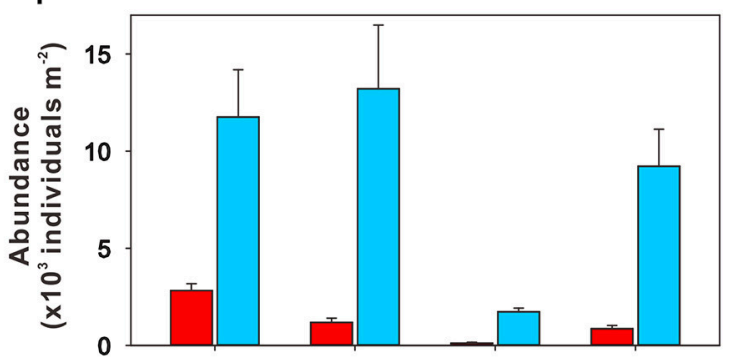

G

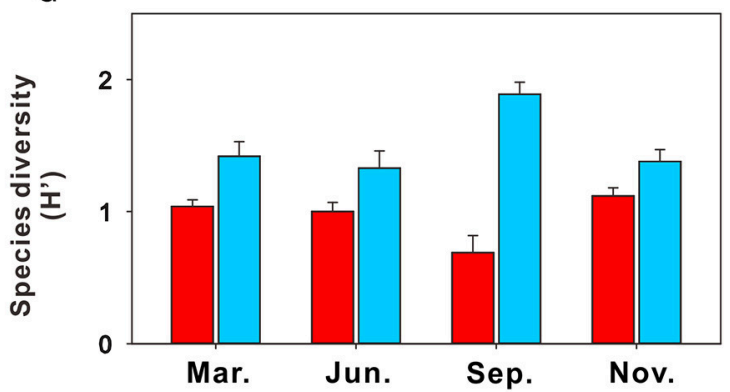

FIGURE 9 | Benthic community changes in Shihwa Bay (SB) before and after construction of a dyke. (A) A map showing the benthic sampling sites in SB (red, inner area; blue, outer area). Variation in (B) the mean number of species (species $\left.0.3 \mathrm{~m}^{-2}\right)$, (C) mean abundance $\left(\times 10^{3}\right.$ individuals $\left.\mathrm{m}^{-2}\right)$, and (D) mean diversity (Shannon diversity index) according to the history of dyke construction. Seasonal variation in (E) the mean number of species (species $\left.0.1 \mathrm{~m}^{-2}\right)$, (F) mean abundance $\left(\times 10^{3}\right.$ individual $\mathrm{m}^{-2}$ ), and (G) mean diversity for the period of 2000-2003. The bars indicate standard errors. The data source is Hwang (2008). 


\section{COMPARISON OF THE NATURAL JB AND ARTIFICIAL SB SYSTEMS: SOURCES OF EUTROPHICATION AND STRATIFICATION}

In both bay systems, bottom-water hypoxia develops due to the combined effects of eutrophication and stratification. However, the sources of eutrophication and stratification that contribute to bottom-water hypoxia development differ between the bays.

First, both bays have undergone a large amount of anthropogenic $\mathrm{N}$ loading from the surrounding land over the past two decades. The main $\mathrm{N}$ sources in JB are land-used waste (45\%) and domestic sewage (45\%), whereas those in SB are domestic sewage (40\%), land-used waste (25\%), and industrial effluents (20\%).

Second, the restricted water circulation, leading to longer water residence times, has stimulated the development and persistence of bottom-water hypoxia in both bays. However, the basic mechanisms of development were totally different. The isolated geomorphology of JB has naturally interrupted exchange between the inshore and offshore waters, which occurs primarily through the narrow Gadeok Channel (Figure 2). In contrast, the construction of an artificial dyke was the main cause in SB.

Third, strong stratification is a key factor in the development of bottom-water hypoxia in both bays; however, the main sources of stratification differed. Thermal stratification (i.e., the vertical temperature gradient) was a more dominant factor in JB, whereas haline stratification (i.e., vertical salinity gradient) was a more significant factor in SB.

In summary, the bottom-water hypoxia in JB can be attributed to anthropogenically derived eutrophication (two main components: land-used waste $>$ domestic sewage) and thermal stratification based on the naturally sluggish water circulation, whereas that in SB is caused by anthropogenically derived eutrophication (three main components: land-used waste $>$ domestic sewage $>$ industrial effluents) and haline stratification based on artificially restricted water circulation.

\section{ADDRESSING UNRESOLVED SCIENTIFIC QUESTIONS FOR FUTURE STUDIES OF KOREAN COASTAL HYPOXIA}

In the previous sections, we reviewed hypoxia in JB and SB in terms of its characteristics, spatiotemporal variation, controlling factors, and significant effects on marine ecosystems. Here, we call attention to some issues that should be urgently resolved in the near future in the JB and SB systems, to enable better understating of coastal hypoxia in the region and help address the growing global concern over this matter (Breitburg et al., 2018).

(1) Bottom-water hypoxia has altered nutrient cycling, reducing the DIN:DIP ratio in the JB. N-limitation in the bottomwater of JB seems to be associated with denitrification and/or excessive P efflux in sediment. On the contrary, $\mathrm{N}$ removal through denitrification seems to be suppressed in SB due to low nitrate availability during desalination era. However, no direct evidence was found to support these arguments. Plimitation, driven by $\mathrm{N}$-dominated eutrophication, was also found in the surface waters of JB. Future research should investigate the influence of nutrient limitations on primary production and whether the unbalanced nutrient cycling structure will change rapidly or be strongly sustained due to rapid anthropogenic modifications.

(2) Algal production (i.e., autochthonous characteristic) is an important source of organic matter for hypoxia formation in both areas. However, supply of terrestrial substances (i.e., allochthonous characteristic) cannot be ignored because both areas are receiving large and different anthropogenic PON loadings. Therefore, further qualitative and quantitative investigation about the contribution of allochthonous and autochthonous POMs to hypoxia dynamics in both areas is necessary.

(3) Coastal hypoxic regions are important contributors to greenhouse gases (e.g., $\mathrm{CO}_{2}, \mathrm{CH}_{4}$, and $\mathrm{N}_{2} \mathrm{O}$ ). Production of greenhouse gases is enhanced substantially in hypoxic waters. Given that the JB hypoxic zones have been expanding significantly, they may be form a significant coastal source region for atmospheric emissions of greenhouse gases. However, coastal greenhouse gases production has not yet been measured in this area.

(4) Significant relationships between bottom-water hypoxia and $\mathrm{pH}$ have been found in the JB and SB systems, implying that hypoxia is associated with "coastal acidification." However, we do not have sufficiently accurate long-term $\mathrm{pH}$ data to confirm this relationship. To assess the impacts of reduced $\mathrm{pH}$ conditions on marine organisms in both bays, we urgently need to conduct long-term $\mathrm{pH}$ monitoring.

(5) In SB, the operation of a TPP has increased seawater exchange rates (5.6-fold) since 2012. However, little information on how the bottom-water conditions have changed is available because detailed surveys in this area have been halted. Therefore, we have no information on whether bottom-water hypoxia in SB is persisting or has disappeared, or on whether the benthic ecosystem in SB is recovering.

This review provides further insight into Korean coastal hypoxia problems, with a focus on the JB and SB systems. We conducted the first review of the Korean coastal hypoxia problem, and believe that it will be helpful in determining the direction of future studies of Korean coastal hypoxia.

\section{AUTHOR CONTRIBUTIONS}

JL and I-NK: developed the idea and wrote the manuscript; JL and J-HL: conducted the literature search and analysis; K-TP and J-EY: provided interpretation of data. All the authors discussed and approved the final manuscript.

\section{ACKNOWLEDGMENTS}

This work was supported by Incheon National University Research Grant in 2016. 


\section{REFERENCES}

Acharyya, T., Sarma, V., Sridevi, B., Venkataramana, V., Bharathi, M., Naidu, S., et al. (2012). Reduced river discharge intensifies phytoplankton bloom in Godavari estuary, India. Mar. Chem. 132, 15-22. doi: 10.1016/j.marchem.2012.01.005

Bae, H., Lee, J.-H., Song, S. J., Park, J., Kwon, B.-O., Hong, S., et al. (2017). Impacts of environmental and anthropogenic stresses on macrozoobenthic communities in Jinhae Bay, Korea. Chemosphere 171, 681-691. doi: 10.1016/j.chemosphere.2016.12.112

Bae, Y. H., Kim, K. O., and Choi, B. H. (2010). Lake Sihwa tidal power plant project. Ocean Eng. 37, 454-463. doi: 10.1016/j.oceaneng.2010.01.015

Bashkin, V., Park, S., Choi, M., and Lee, C. (2002). Nitrogen budgets for the Republic of Korea and the Yellow Sea region. Biogeochemistry 57, 387-403. doi: 10.1023/A:1015767506197

Boesch, D. F., and Rabalais, N. N. (1991). Effects of hypoxia on continental shelf benthos: comparisons between the New York Bight and the Northern Gulf of Mexico. Geol. Soc. London Spec. Publ. 58, 27-34. doi: 10.1144/GSL.SP.1991.058.01.02

Breitburg, D., Levin, L. A., Oschlies, A., Grégoire, M., Chavez, F. P., Conley, D. J., et al. (2018). Declining oxygen in the global ocean and coastal waters. Science 359:eaam7240. doi: 10.1126/science.aam7240

Byun, D., Wang, X., and Holloway, P. (2004). Tidal characteristic adjustment due to dyke and seawall construction in the Mokpo Coastal Zone, Korea. Estuar. Coast. Shelf Sci. 59, 185-196. doi: 10.1016/j.ecss.2003.08.007

Cai, W.-J., Hu, X., Huang, W.-J., Murrell, M. C., Lehrter, J. C., Lohrenz, S. E., et al. (2011). Acidification of subsurface coastal waters enhanced by eutrophication. Nat. Geosci. 4, 766-770. doi: 10.1038/ngeo1297

Canfield, D. E., Thamdrup, B., and Hansen, J. W. (1993). The anaerobic degradation of organic matter in Danish coastal sediments: iron reduction, manganese reduction, and sulfate reduction. Geochim. Cosmochim. Acta 57, 3867-3883. doi: 10.1016/0016-7037(93)90340-3

Cao, W., and Wong, M. H. (2007). Current status of coastal zone issues and management in China: a review. Environ. Int. 33, 985-992. doi: 10.1016/j.envint.2007.04.009

Chang, W. K., Ryu, J., Yi, Y., Lee, W.-C., Lee, C.-W., Kang, D., et al. (2012). Improved water quality in response to pollution control measures at Masan Bay, Korea. Mar. Pollut. Bull. 64, 427-435. doi: 10.1016/j.marpolbul.2011.11.011

Childs, C. R., Rabalais, N. N., Turner, R. E., and Proctor, L. M. (2002). Sediment denitrification in the Gulf of Mexico zone of hypoxia. Mar. Ecol. Prog. Ser. 240, 285-290. doi: 10.3354/meps 240285

Cho, C. H. (1979). Mass mortalities of oyster due to red tide in Jinhae Bay in 1978. Korean J. Fish. Aquat. Sci. 12, 27-33.

Cho, C. H. (1991). Mariculture and eutrophication in Jinhae bay, Korea. Mar. Pollut. Bull. 23, 275-279. doi: 10.1016/0025-326X(91)90687-N

Cho, D. O. (2005). Lessons learned from Lake Shiwha project. Coast. Manage. 33, 315-334. doi: 10.1080/08920750590952036

Cho, H. Y., Chae, J. W., and Chun, S. Y. (2002). Stratification and DO concentration change in Chinhae-Masan Bay. J. Korean Soc. Coast. Ocean. Eng. 14, 295-307.

Choi, J. K., Lee, E. H., Noh, J. H., and Huh, S. H. (1997). The study on the phytoplankton bloom and primary productivity in lake Shihwa and adajcent coastal areas. J. Oceanol. Soc. Korea 2, 78-86.

Choi, J.-H. (2001). Construction of Shihwa Dyke and Marine Environmental Changes in the Shihwa Reservoir, Western Coast of Korea. dissertation thesis, Seoul National University, Seoul.

Choi, K., Kim, S., Kim, D., Oh, Y., Heo, W., Lee, Y., et al. (2008). Temporal and spatial distributions of basic water quality in the upper regions of brackish Lake Sihwa with a limited water exchange. Korean J. Limnol. 41, 206-215.

Christensen, P. B., Nielsen, L. P., Sørensen, J., and Revsbech, N. P. (1990). Denitrification in nitrate-rich streams: diurnal and seasonal variation related to benthic oxygen metabolism. Limnol. Oceanogr. 35, 640-651. doi: 10.4319/lo.1990.35.3.0640

Conley, D.J., Björck, S., Bonsdorff, E., Carstensen, J., Destouni, G., Gustafsson, B.G., et al. (2009a). Hypoxia-related processes in the Baltic Sea. Environ. Sci. Technol. 43, 3412-3420. doi: 10.1021/es802762a.
Conley, D. J., Carstensen, J., Vaquer-Sunyer, R., and Duarte, C. M. (2009b). Ecosystem thresholds with hypoxia. Hydrobiologia 629, 21-29. doi: 10.1007/s10750-009-9764-2

Conley, D. J., Humborg, C., Rahm, L., Savchuk, O. P., and Wulff, F. (2002). Hypoxia in the Baltic Sea and basin-scale changes in phosphorus biogeochemistry. Environ. Sci. Technol. 36, 5315-5320. doi: 10.1021/ es025763w

Dagg, M. J., Ammerman, J. W., Amon, R. M., Gardner, W. S., Green, R. E., and Lohrenz, S. E. (2007). A review of water column processes influencing hypoxia in the northern Gulf of Mexico. Estuar. Coast. 30, 735-752. doi: $10.1007 / \mathrm{BF} 02841331$

Dalsgaard, T., Thamdrup, B., and Canfield, D. E. (2005). Anaerobic ammonium oxidation (anammox) in the marine environment. Res. Microbiol. 156, 457-464. doi: 10.1016/j.resmic.2005.01.011

Degobbis, D., Gilmartin, M., and Revelante, N. (1986). An annotated nitrogen budget calculation for the northern Adriatic Sea. Mar. Chem. 20, 159-177. doi: 10.1016/0304-4203(86)90037-X

Diaz, R. J. (2001). Overview of hypoxia around the world. J. Environ. Qual. 30, 275-281. doi: 10.2134/jeq2001.302275x

Diaz, R. J., and Rosenberg, R. (1995). Marine benthic hypoxia: a review of its ecological effects and the behavioural responses of benthic macrofauna. Oceanogr. Mar. Biol. Annu. Rev. 33, 245-203.

Diaz, R. J., and Rosenberg, R. (2008). Spreading dead zones and consequences for marine ecosystems. Science 321, 926-929. doi: 10.1126/science.1156401

Frey, R. W., Howard, J. D., Han, S.-J., and Park, B.-K. (1989). Sediments and sedimentary sequences on a modern macrotidal flat, Inchon, Korea. J. Sediment. Res. 59, 28-44.

Gächter, R., and Meyer, J. S. (1993). "The role of microorganisms in mobilization and fixation of phosphorus in sediments," in Proceedings of the Third International Workshop on Phosphorus in Sediments, eds P. C. M. Boers, T. E. Cappenberg, and W. van Raaphorst (Dordrecht: Springer), 103-121.

Gamenick, I., Jahn, A., Vopel, K., and Giere, O. (1996). Hypoxia and sulphide as structuring factors in a macrozoobenthic community on the Baltic Sea shore: colonisation studies and tolerance experiments. Mar. Ecol. Prog. Ser. 144, 73-85. doi: 10.3354/meps144073

Gazeau, F., Quiblier, C., Jansen, J. M., Gattuso, J. P., Middelburg, J. J., and Heip, C. H. (2007). Impact of elevated $\mathrm{CO}_{2}$ on shellfish calcification. Geophys. Res. Lett. 34:L07603. doi: 10.1029/2006GL028554

Gedan, K. B., Silliman, B. R., and Bertness, M. D. (2009). Centuries of humandriven change in salt marsh ecosystems. Ann. Rev. Mar. Sci. 1, 117-141. doi: 10.1146/annurev.marine.010908.163930

Gustafsson, B. G., and Stigebrandt, A. (2007). Dynamics of nutrients and oxygen/hydrogen sulfide in the Baltic Sea deep water. J. Geophys. Res. Biogeosci. 112:G02023. doi: 10.1029/2006JG000304

Hagy, J. D., Boynton, W. R., Keefe, C. W., and Wood, K. V. (2004). Hypoxia in Chesapeake Bay, 1950-2001: long-term change in relation to nutrient loading and river flow. Estuaries 27, 634-658. doi: 10.1007/BF02 907650

Han, M. W., and Park, Y. C. (1999). The development of anoxia in the artificial Lake Shihwa, Korea, as a consequence of intertidal reclamation. Mar. Pollut. Bull. 38, 1194-1199. doi: 10.1016/S0025-326X(99) 00161-7

Han, M. W., Park, Y. C., and Huh, S.-H. (1997). Benthic fluxes of ammonia and lead in Lake Shihwa. J. Oceanol. Soc. Korea 2, 69-77.

Hong, G. H., Kim, K. T., Pae, S. J., Kim, S. H., and Lee, S. H. (1991). Annual cycles of nutrients and dissolved oxygen in a nutrient-rich temperate coastal bay, Chinhae Bay, Korea. J. Oceanol. Soc. Korea 26, 204-222.

Hong, J.-S. (1987). Summer oxygen deficiency and benthic biomass in the Chinhae Bay system. J. Oceanol. Soc. Korea 22, 246-256.

Hong, J.-S., Jung, R.-H., Seo, I.-S., Yoon, K.-T., Choi, B.-M., and Yoo, J.-W. (1997). How are the spatio-temporal distribution patterns of benthic macrofaunal communities affected by the construction of Shihwa Dike in the west coast of Korea? Korean J. Fish. Aquat. Sci. 30, 882-895.

Hong, S. H. (2016). The Characteristic of Tidal Current and Temperature in Jinhae Bay by Numerical Model Experiments. Master's thesis, Chonnam National University, Yeosu.

Howarth, R. W. (2008). Coastal nitrogen pollution: a review of sources and trends globally and regionally. Harmful Algae 8, 14-20. doi: 10.1016/j.hal.2008.08.015 
Howarth, R., Chan, F., Conley, D. J., Garnier, J., Doney, S. C., Marino, R., et al. (2011). Coupled biogeochemical cycles: eutrophication and hypoxia in temperate estuaries and coastal marine ecosystems. Front. Ecol. Environ. 9, 18-26. doi: 10.1890/100008

Hwang, I. S. (2008). A Decadal Change of Macrobenthic Community in Lake Sihwa under Periodic Hypoxia. dissertation thesis, Inha University, Incheon.

IPCC (2013). Climate Change 2013: the Physical Science Basis: Working Group I Contribution to the Fifth Assessment Report of the Intergovernmental Panel on Climate Change eds T. F. Stocker, D. Qin, G.-K. Plattner, M. Tignor, S. K. Allen, J. Boschung, A. Nauels, Y. Xia, V. Bex, and P. M. Midgley (Cambridge: Cambridge Univ. Press), 2013.

Jang, J.-I., Han, I., Kim, K.-T., and Ra, K. (2011). Spatial characteristics of pollutant concentrations in the streams of Shihwa lake. J. Korean Soc. Environ. Eng. 33, 289-299. doi: 10.4491/KSEE.2011.33.4.289

Jang, P.-G., Shin, K., Chang, M., and Kim, D. (2011). Spatial and temporal trends in water quality in response to sewage discharge in Masan and Hangam Bays, Korea. J. Coastal Res. 27, 144-155. doi: 10.2112/JCOASTRES-D-11-00023.1

Jensen, H. S., Mortensen, P. B., Andersen, F., Rasmussen, E., and Jensen, A. (1995). Phosphorus cycling in a coastal marine sediment, Aarhus Bay, Denmark. Limnol. Oceanogr. 40, 908-917. doi: 10.4319/lo.1995.40.5.0908

Jung, K. Y., Ro, Y. J., Choi, Y. H., and Kim, B. J. (2015). Hypoxia in a transient estuary caused by summer lake-water discharge from artificial dykes into Chunsu Bay, Korea. Mar. Pollut. Bull. 95, 47-62. doi: 10.1016/j.marpolbul.2015.04.043

Jung, R.-H., Choi, M., Yoon, S.-P., Lee, W.-C., and Choi, H.-G. (2012). Polychaete community structure from Inshore and offshore of Lake Shihwa (Korea) in March, 2008. Korean J. Fish. Aquat. Sci. 45, 56-64. doi: 10.5657/KFAS. 2012.0056

Kang, N. S., Lee, K. H., Jeong, H. J., Du Yoo, Y., Seong, K. A., Potvin, É., et al. (2013a). Red tides in Shiwha Bay, western Korea: a huge dike and tidal power plant established in a semi-enclosed embayment system. Harmful Algae 30, S114-S130. doi: 10.1016/j.hal.2013.10.011

Kang, Y. S., Chae, Y., and Lee, H. R. (2013b). Changes in sea water characteristics due to operation of Shihwa tidal power plant. J. Korean Soc. Coast. Ocean Eng. 25, 219-235. doi: 10.9765/KSCOE.2013.25.4.219

Kasai, A., Yamada, T., and Takeda, H. (2007). Flow structure and hypoxia in Hiuchi-nada, Seto Inland Sea, Japan. Estuar. Coast. Shelf. Sci. 71, 210-217. doi: 10.1016/j.ecss.2006.08.001

Keeling, R. F., Körtzinger, A., and Gruber, N. (2010). Ocean deoxygenation in a warming world. Annu. Rev. Mar. Sci. 2, 199-229 doi: 10.1146/annurev.marine.010908.163855

Kemp, W. M., Sampou, P., Garber, J., Tuttle, J., and Boynton, W. (1992). Seasonal depletion of oxygen from bottom waters of Chesapeake Bay: roles of benthic and planktonic respiration and physical exchange processes. Mar. Ecol. Prog. Ser. 85, 137-152. doi: 10.3354/meps085137

Kemp, W., Sampou, P., Caffrey, J., Mayer, M., Henriksen, K., and Boynton, W. R. (1990). Ammonium recycling versus denitrification in Chesapeake Bay sediments. Limnol. Oceanogr. 35, 1545-1563. doi: 10.4319/lo.1990.35.7.1545

Kim, C.-K., and Lee, P.-Y. (1994). Water mass structure and dissolved oxygen distribution in Chinhae Bay. Korean J. Fish. Aquat. Sci. 27, 572-582.

Kim, D., Baek, S. H., Yoon, D.-Y., Kim, K.-H., Jeong, J.-H., Jang, P.-G., et al. (2014). Water quality assessment at Jinhae Bay and Gwangyang Bay, South Korea. Ocean Sci. J. 49, 251-264. doi: 10.1007/s12601-014-0026-5

Kim, D., Choi, H., Choi, S., Baek, S., Kim, K., Jeong, J., et al. (2013a). Spatial and seasonal variations in the water quality of Jinhae Bay, Korea. New Zeal. J. Mar. Fresh. 47, 192-207. doi: 10.1080/00288330.2013.772066

Kim, D., Choi, S.-H., Yang, E.-J., Kim, K.-H., Jeong, J.-H., and Kim, Y. O. (2013b). Biologically mediated seasonality of aragonite saturation states in Jinhae Bay, Korea. J. Coast. Res. 29, 1420-1426. doi: 10.2112/JCOASTRES-D-1200205.1

Kim, D., Lee, C.-W., Choi, S.-H., and Kim, Y. O. (2012). Long-term changes in water quality of Masan Bay, Korea. J. Coast. Res. 28, 923-929. doi: 10.2112/JCOASTRES-D-11-00165.1

Kim, D., Lim, D.-I., Jeon, S.-K., and Jung, H.-S. (2005). Chemical characteristics and eutrophication in Cheonsu Bay, west coast of Korea. Ocean Polar Res. 27, 45-58. doi: 10.4217/OPR.2005.27.1.045

Kim, E. S., Cho, S. R., Kang, D. J., and Hwang, H. M. (1994). Stable carbon isotope ratios of particular organic matters in Masan Bay. Ocean Res. 16, 29-34.
Kim, H. G. (1997). Recent harmful algal blooms and mitigation strategies in Korea. Ocean Polar Res. 19, 185-192.

Kim, H. W., Joo, G. J., and Walz, N. (2001). Zooplankton dynamics in the hyper-eutrophic Nakdong River system (Korea) regulated by an estuary dam and side channels. Int. Rev. Hydrobiol. 86, 127-143. doi: 10.1002/15222632(200101)86:1<127::AID-IROH127>3.0.CO;2-F

Kim, J. B., Hong, S., Lee, W.-C., Lee, Y.-W., Kim, H. C., and Cho, Y. (2015). Evaluation of phytoplankton community composition in the eutrophic Masan Bay by HPLC pigment analysis. J. Environ. Biol. 36, 491-498.

Kim, J. B., Lee, S. Y., Yu, J., Choi, Y. H., Jung, C.-S., and Lee, P.-Y. (2006). The characteristics of oxygen deficient water mass in Gamak Bay. J. Korean Soc. Mar. Environ. Energy 9, 216-224.

Kim, J. M., Han, S. J., and Lee, J. W. (1976). Environmental studies on Masan bay 1. Physical factors and chemical contents. J. Oceanol. Soc. Korea 11, 25-33.

Kim, N. S., Kang, H., Kwon, M.-S., Jang, H.-S., and Kim, J. G. (2016). Comparison of seawater exchange rate of small scale inner bays within Jinhae Bay. J. Korean Soc. Mar. Environ. Energy 19, 74-85. doi: 10.7846/JKOSMEE.2016. 19.1.74

Kim, S.-Y., Lee, Y.-H., Kim, Y.-S., Shim, J.-H., Ye, M.-J., Jeon, J.-W., et al. (2012). Characteristics of marine environmental in the hypoxic season at Jinhae Bay in 2010. Korea J. Nat. Conserv. 6, 115-129. doi: 10.11624/KJNC.2012.6.2.115

Kim, T. I., Choi, B. H., and Lee, S. W. (2006). Hydrodynamics and sedimentation induced by large-scale coastal developments in the Keum River Estuary, Korea. Estuar. Coast. Shelf. Sci. 68, 515-528. doi: 10.1016/j.ecss.2006. 03.003

Kim, Y. J., Kim, M. K., and Yoon, J. S. (2010). Study of formation and development of oxygen deficient water mass, using ecosystem model in Jinhae, Masan Bay. J. Ocean Eng. Technol. 24, 41-50.

Kim, Y.-O., Park, M.-H., and Han, M.-S. (2002). Role of cyst germination in the bloom initiation of Alexandrium tamarense (Dinophyceae) in Masan Bay, Korea. Aquat. Microb. Ecol. 29, 279-286. doi: 10.3354/ame029279

Kim, Y.-S., Lee, Y.-H., Kwon, J.-N., and Choi, H.-G. (2015). The effect of low oxygen conditions on biogeochemical cycling of nutrients in a shallow seasonally stratified bay in southeast Korea (Jinhae Bay). Mar. Pollut. Bull. 95, 333-341. doi: 10.1016/j.marpolbul.2015.03.022

Kwon, J.-N., Lee, J., Kim, Y., Lim, J.-H., Choi, T.-J., Ye, M.-J., et al. (2014). Longterm variations of water quality in Jinhae Bay. J. Korean Soc. Mar. Environ. Energy 17, 324-332. doi: 10.7846/JKOSMEE.2014.17.4.324

Lee, B. (2017). Impact of Increasing Tidal Mixing on the Water Quality in Shihwa Coastal Reservoir. dissertation thesis, Myongji University, Seoul.

Lee, C.-H., Lee, B.-Y., Chang, W. K., Hong, S., Song, S. J., Park, J., et al. (2014). Environmental and ecological effects of Lake Shihwa reclamation project in South Korea: a review. Ocean Coast. Manage. 102, 545-558. doi: 10.1016/j.ocecoaman.2013.12.018

Lee, C.-K., Park, T.-G., Park, Y.-T., and Lim, W.-A. (2013). Monitoring and trends in harmful algal blooms and red tides in Korean coastal waters, with emphasis on Cochlodinium polykrikoides. Harmful Algae 30, S3-S14. doi: $10.1016 /$ j.hal.2013.10.002

Lee, C.-W., and Min, B.-Y. (1990). Pollution in Masan Bay, a matter of concern in South Korea. Mar. Pollut. Bull. 21, 226-229. doi: 10.1016/0025-326X(90)90338-9

Lee, H. J., and Lee, S. H. (2012). Geological consequences of the Saemangeum Dyke, mid-west coast of korea: a review. Ocean Sci. J. 47, 395-410. doi: $10.1007 / \mathrm{s} 12601-012-0037-\mathrm{z}$

Lee, I.-C., Oh, Y. J., and Kim, H.-T. (2008). Annual variation in oxygen-deficient water mass in Jinhae Bay, Korea. Korean J. Fish. Aquat. Sci. 41, 134-139. doi: $10.5657 / \mathrm{kfas} .2008 .41 .2 .134$

Lee, J. S., Kim, K. H., Shim, J., Han, J. H., Choi, Y. H., and Khang, B.-J. (2012). Massive sedimentation of fine sediment with organic matter and enhanced benthic-pelagic coupling by an artificial dyke in semi-enclosed Chonsu Bay, Korea. Mar. Pollut. Bull. 64, 153-163. doi: 10.1016/j.marpolbul.2011. 09.033

Lee, J., Kim, S.-G., and An, S. (2017). Dynamics of the physical and biogeochemical processes during hypoxia in Jinhae Bay, South Korea. J. Coast. Res. 33, 854-863. doi: 10.2112/JCOASTRES-D-16-00122.1

Lee, J.-H., Park, J.-Y., Lee, H.-G., Park, H.-S., and Kim, D. (2003). Environmental assessment of the Shihwa Lake by using the benthic pollution index. Ocean Polar Res. 25, 183-200. doi: 10.4217/OPR.2003.25.2.183 
Lee, M.-O., and Kim, J.-K. (2008). Characteristics of algal blooms in the southern coastal waters of Korea. Mar. Environ. Res. 65, 128-147. doi: 10.1016/j.marenvres.2007.09.006

Lee, S. Y., and Khim, J. S. (2017). Hard science is essential to restoring soft-sediment intertidal habitats in burgeoning East Asia. Chemosphere 168, 765-776. doi: 10.1016/j.chemosphere.2016.10.136

Levin, L., Ekau, W., Gooday, A., Jorissen, F., Middelburg, J., Naqvi, S., et al. (2009). Effects of natural and human-induced hypoxia on coastal benthos. Biogeosciences 6, 2063-2098. doi: 10.5194/bg-6-2063-2009

Lim, D.-I., Jung, H. S., Kim, K. T., Shin, H. H., and Jung, S. W. (2012). Sedimentary records of metal contamination and eutrophication in Jinhae-Masan Bay, Korea. Mar. Pollut. Bull. 64, 2542-2548. doi: 10.1016/j.marpolbul.2012. 07.033

Lim, D.-I., Kim, Y.-O., Kang, M. R., Jang, P.-K., Shin, K., and Jang, M. (2007). Variability of water quality and limiting factor for primary production in semi-enclosed Masan Bay, South Sea of Korea. Ocean Polar Res. 29, 349-366. doi: 10.4217/OPR.2007.29.4.349

Lim, H.-S., and Hong, J.-S. (1994). Ecology of the macrobenthic community in Chinhae Bay, Korea-1. Benthic environment. Korean J. Fish. Aquat. Sci. 27, 200-214.

Lim, H.-S., Diaz, R. J., Hong, J.-S., and Schaffner, L. C. (2006). Hypoxia and benthic community recovery in Korean coastal waters. Mar. Pollut. Bull. 52, 1517-1526. doi: 10.1016/j.marpolbul.2006.05.013

Melzner, F., Thomsen, J., Koeve, W., Oschlies, A., Gutowska, M. A., Bange, H. W., et al. (2013). Future ocean acidification will be amplified by hypoxia in coastal habitats. Mar. Biol. 160, 1875-1888. doi: 10.1007/s00227-012-1954-1

Middelburg, J., and Levin, L. (2009). Coastal hypoxia and sediment biogeochemistry. Biogeosciences 6, 1273-1293. doi: 10.5194/bg-6-1273-2009

MOF (2005). Study on Improvement of Marine Environments in the Shihwa Coastal Reservoir. Seoul: Ministry of Oceans and Fisheries.

MOF (2006). Study on Improvement of Marine Environments in the Shihwa Coastal Reservoir. Seoul: Ministry of Oceans and Fisheries.

MOF (2007). Study on Improvement of Marine Environments in the Shihwa Coastal Reservoir. Seoul: Ministry of Oceans and Fisheries.

MOF (2008). Study on Improvement of Marine Environments in the Shihwa Coastal Reservoir. Seoul: Ministry of Oceans and Fisheries.

MOF (2009). Study on Improvement of Marine Environments in the Shihwa Coastal Reservoir. Seoul: Ministry of Oceans and Fisheries.

MOF (2010). Study on Improvement of Marine Environments in the Shihwa Coastal Reservoir. Seoul: Ministry of Oceans and Fisheries.

MOF (2011). Study on Improvement of Marine Environments in the Shihwa Coastal Reservoir. Seoul: Ministry of Oceans and Fisheries.

MOF (2013). Study on the Total Pollution Loads Management System in Masan Bay, a Special Management Area and Terrestrial Pollution Source Management. Seoul: Ministry of Oceans and Fisheries.

MOF (2016). Development of Hypoxic Water Mass Restoration Technology in an Inner Bay. Seoul: Ministry of Oceans and Fisheries.

Murrell, M. C., and Lehrter, J. C. (2011). Sediment and lower water column oxygen consumption in the seasonally hypoxic region of the Louisiana continental shelf. Estuar. coast. 34, 912-924. doi: 10.1007/s12237-010-9351-9

NIFS (2009). Hypoxic Water Mass in Korea. Busan, National Institute for Fusion Science.

NIFS (2012). Standard Manual of Pacific Oyster Hanging Culture. Busan, National Institute for Fusion Science.

NIFS (2017). Annual Report of Marine Environment Monitoring around Aquaculture Area in Korea. National Institute for Fusion Science, Busan.

Park, J. K., Kim, E. S., Cho, S. R., Kim, K. T., and Park, Y. C. (2003). Annual variation of water qualities in the Shihwa Lake. Ocean Polar Res. 25, 459-468. doi: 10.4217/OPR.2003.25.4.459

Park, S. (2016). Organic Matter and Nutrient Dynamics with the Development of Hypoxia in Jinhae Bay, Korea. Master's thesis, Pusan National University, Busan.

Park, Y. C., Park, J. K., Han, M. W., Son, S. K., Kim, M. K., and Huh, S. H. (1997). Biogeochemical study of dissolved organic and inorganic compounds under oxic/anoxic environment in Lake Shihwa. J. Oceanol. Soc. Korea 2, 53-68.

Pearson, T., and Rosenberg, R. (1978). Macrobenthic succession in relation to organic enrichment and pollution of the marine environment. Oceanogr. Mar. Biol. Ann. Rev. 16, 229-311.
Portnoy, J. (1991). Summer oxygen depletion in a diked New England estuary. Estuar. coast. 14, 122-129. doi: 10.2307/ 1351685

Portnoy, J., and Giblin, A. (1997). Effects of historic tidal restrictions on salt marsh sediment chemistry. Biogeochemistry 36, 275-303. doi: 10.1023/A:1005715520988

Ra, K., Kim, J.-K., Kim, E.-S., Kim, K.-T., Lee, J.-M., Kim, S.-K., et al. (2013). Evaluation of spatial and temporal variations of water quality in Lake Shihwa and outer sea by using water quality index in Korea: a case study of influence of Tidal Power Plant operation. J. Korean Soc. Mar. Environ. Energy 16, 102-114. doi: 10.7846/JKOSMEE.2013. 16.2.102

Rabalais, N. N., Turner, R. E., and Wiseman, W. J. (2001). Hypoxia in the Gulf of Mexico. J. Environ. Qual. 30, 320-329. doi: 10.2134/jeq2001. 302320x

Rabalais, N. N., Turner, R. E., Justic, D., Dortch, Q., and Wiseman, W. J. Jr. (1999). Characterization of Hypoxia: Topic 1 Report for the Integrated Assessment on Hypoxia in the Gulf of Mexico. NOAA Coastal Ocean Program, Silver Spring, MD. 167.

Rabalais, N., Diaz, R., Levin, L., Turner, R., Gilbert, D., and Zhang, J. (2010). Dynamics and distribution of natural and human-caused hypoxia. Biogeosciences 7, 585-619. doi: 10.5194/bg-7-585-2010

Rivera, Z. J. Q., Wissel, B., Rabalais, N. N., and Justića, D. (2010). Effects of biological and physical factors on seasonal oxygen dynamics in a stratified, eutrophic coastal ecosystem. Limnol. Oceanogr. 55, 289-304. doi: 10.4319/lo.2010.55.1.0289

Rowe, G. T., Kaegi, M. E. C., Morse, J. W., Boland, G. S., and Briones, E. G. E. (2002). Sediment community metabolism associated with continental shelf hypoxia, northern Gulf of Mexico. Estuaries 25, 1097-1106. doi: $10.1007 / \mathrm{BF} 02692207$

Ryu, J.-S., Choi, J.-W., Kang, S.-G., Koh, C.-H., and Huh, S.-H. (1997). Temporal and spatial changes in the species composition and abundance of benthic polychaetes after the construction of Shihwa dike (west coast of Korea). J. Oceanol. Soc. Korea 2, 101-109.

Seitzinger, S. P., and Giblin, A. E. (1996). "Estimating denitrification in North Atlantic continental shelf sediments," in Nitrogen Cycling in the North Atlantic Ocean and its Watersheds, ed R. W. Howarth (Dordrecht: Springer), 235-260.

Seo, J.-Y., Park, S.-H., Lee, J.-H., and Choi, J.-W. (2012). Structural changes in macrozoobenthic communities due to summer hypoxia in Gamak Bay, Korea. Ocean Sci. J. 47, 27-40. doi: 10.1007/s12601-0120003-9

Shin, H. H., Jung, S. W., Jang, M.-C., and Kim, Y.-O. (2013). Effect of pH on the morphology and viability of Scrippsiella trochoidea cysts in the hypoxic zone of a eutrophied area. Harmful Algae 28, 37-45. doi: 10.1016/j.hal.2013. 05.011

Sin, Y., Hyun, B., Jeong, B., and Soh, H. Y. (2013). Impacts of eutrophic freshwater inputs on water quality and phytoplankton size structure in a temperate estuary altered by a sea dike. Mar. Environ. Res. 85, 54-63. doi: 10.1016/j.marenvres.2013.01.001

Tamai, K. (1993). Tolerance of Theora fragilis (Bivalvia: Semelidae) to low concentrations of dissolved oxygen. Nippon Suisan Gakk. 59, 615-620. doi: 10.2331 /suisan. 59.615

Tockner, K., and Stanford, J. A. (2002). Riverine flood plains: present state and future trends. Environ. Conserv. 29, 308-330. doi: 10.1017/S037689290 $200022 \mathrm{X}$

Tsutsumi, H. (2006). Critical events in the Ariake Bay ecosystem: clam population collapse, red tides, and hypoxic bottom water. Plank. Benthos Res. 1, 3-25. doi: $10.3800 /$ pbr. 1.3

Tuominen, L., Heinänen, A., Kuparinen, J., and Nielsen, L. P. (1998). Spatial and temporal variability of denitrification in the sediments of the northern Baltic Proper. Mar. Ecol. Prog. Ser. 172, 13-24. doi: 10.3354/ meps172013

Vaquer-Sunyer, R., and Duarte, C. M. (2008). Thresholds of hypoxia for marine biodiversity. Proc. Natl. Acad. Sci. U.S.A. 105, 15452-15457. doi: $10.1073 /$ pnas. 0803833105

Voss, M., Emeis, K. C., Hille, S., Neumann, T., and Dippner, J. (2005). Nitrogen cycle of the Baltic Sea from an isotopic perspective. Global Biogeochem. Cycles 19:GB3001. doi: 10.1029/2004GB002338 
Welsh, B. L., and Eller, F. C. (1991). Mechanisms controlling summertime oxygen depletion in western Long Island Sound. Estuar. Coast. 14, 265-278. doi: $10.2307 / 1351661$

Ye, M. (2015). A Study on the Development Mode of Hypoxia Event in the Jinhae Bay during 2011-2013, and Predictability of Hypoxia using Weather Parameters. Master's thesis, Pusan National University, Busan.

Yoo, J. K. (2010). Spatio-temporal Variation of Mesozooplankton Community in Lake Sihwa and Coastal Waters outside the Lake, Korea, and the Physio-ecological Characteristics of Predominant Copepods Acartia hudsonica and A. sinjiensis. dissertation thesis, Inha University, Incheon.
Conflict of Interest Statement: The authors declare that the research was conducted in the absence of any commercial or financial relationships that could be construed as a potential conflict of interest.

Copyright (c) 2018 Lee, Park, Lim, Yoon and Kim. This is an open-access article distributed under the terms of the Creative Commons Attribution License (CC $B Y)$. The use, distribution or reproduction in other forums is permitted, provided the original author(s) and the copyright owner are credited and that the original publication in this journal is cited, in accordance with accepted academic practice. No use, distribution or reproduction is permitted which does not comply with these terms. 